University of Wollongong

Research Online

Faculty of Engineering and Information

Faculty of Engineering and Information

Sciences - Papers: Part B

Sciences

2018

\title{
Application of geoinclusions for sustainable rail infrastructure under increased axle loads and higher speeds
}

Buddhima Indraratna

University of Wollongong, indra@uow.edu.au

Fernanda Bessa Ferreira

University of Wollongong

Yujie Qi

University of Wollongong, qyujie@uow.edu.au

Ngoc Trung Ngo

University of Wollongong, trung@uow.edu.au

Follow this and additional works at: https://ro.uow.edu.au/eispapers1

Part of the Engineering Commons, and the Science and Technology Studies Commons

Research Online is the open access institutional repository for the University of Wollongong. For further information contact the UOW Library: research-pubs@uow.edu.au 


\title{
Application of geoinclusions for sustainable rail infrastructure under increased axle loads and higher speeds
}

\begin{abstract}
Given the ongoing demand for faster trains for carrying heavier loads, conventional ballasted railroads require considerable upgrading in order to cope with the increasing traffic-induced stresses. During train operations, ballast deteriorates due to progressive breakage and fouling caused by the infiltration of fine particles from the surface or mud-pumping from the underneath layers (e.g. sub-ballast, sub-grade), which decreases the load bearing capacity, impedes drainage and increases the deformation of ballasted tracks. Suitable ground improvement techniques involving geosynthetics and resilient rubber sheets are commonly employed to enhance the stability and longevity of rail tracks. This keynote paper focuses mainly on research projects undertaken at the University of Wollongong to improve track performance by emphasising the main research outcomes and their practical implications. Results from laboratory tests, computational modelling and field trials have shown that track behaviour can be significantly improved by the use of geosynthetics, energy-absorbing rubber mats, rubber crumbs and infilled-recycled tyres. Fullscale monitoring of instrumented track sections supported by rail industry (ARTC) has been performed, and the obtained field data for in situ stresses and deformations could verify the track performance, apart from validating the numerical simulations. The research outcomes provide promising approaches that can be incorporated into current track design practices to cater for high-speed freight trains carrying heavier loads.
\end{abstract}

\section{Keywords}

infrastructure, rail, sustainable, geoinclusions, higher, application, speeds, increased, loads, under, axle

\section{Disciplines}

Engineering | Science and Technology Studies

\section{Publication Details}

Indraratna, B., Ferreira, F. Bessa., Qi, Y. \& Ngo, T. Ngoc. (2018). Application of geoinclusions for sustainable rail infrastructure under increased axle loads and higher speeds. Innovative Infrastructure Solutions, 3 69-1-69-21. 


\title{
Application of geoinclusions for sustainable rail infrastructure under increased axle loads and higher speeds
}

\author{
Buddhima Indraratna $^{1}\left[\right.$ D Fernanda Bessa Ferreira ${ }^{1} \cdot$ Yujie $\mathbf{Q j}^{1} \cdot$ Trung Ngoc Ngo $^{1}$
}

Received: 7 August 2018 / Accepted: 19 September 2018

(c) Springer Nature Switzerland AG 2018

\begin{abstract}
Given the ongoing demand for faster trains for carrying heavier loads, conventional ballasted railroads require considerable upgrading in order to cope with the increasing traffic-induced stresses. During train operations, ballast deteriorates due to progressive breakage and fouling caused by the infiltration of fine particles from the surface or mud-pumping from the underneath layers (e.g. sub-ballast, sub-grade), which decreases the load bearing capacity, impedes drainage and increases the deformation of ballasted tracks. Suitable ground improvement techniques involving geosynthetics and resilient rubber sheets are commonly employed to enhance the stability and longevity of rail tracks. This keynote paper focuses mainly on research projects undertaken at the University of Wollongong to improve track performance by emphasising the main research outcomes and their practical implications. Results from laboratory tests, computational modelling and field trials have shown that track behaviour can be significantly improved by the use of geosynthetics, energy-absorbing rubber mats, rubber crumbs and infilled-recycled tyres. Full-scale monitoring of instrumented track sections supported by rail industry (ARTC) has been performed, and the obtained field data for in situ stresses and deformations could verify the track performance, apart from validating the numerical simulations. The research outcomes provide promising approaches that can be incorporated into current track design practices to cater for high-speed freight trains carrying heavier loads.
\end{abstract}

Keywords Ballast $\cdot$ Geogrid $\cdot$ Rubber crumb $\cdot$ Scrap tyre $\cdot$ Rail infrastructure $\cdot$ Discrete element modelling

\section{Introduction}

The rail networks play an important role in transporting commodities and passengers around the globe. Australia is at the pinnacle in relation to heavy haul train operations often involving 3-5-km-long trains with axle loads up to 40 tonnes [18]. However, these heavy freight trains demand safe and economic track design to withstand the large cyclic

Buddhima Indraratna

indra@uow.edu.au

Fernanda Bessa Ferreira

fernanda@uow.edu.au

Yujie Qi

qyujie@uow.edu.au

Trung Ngoc Ngo

trung@uow.edu.au

1 Centre for Geomechanics and Railway Engineering (CGRE) and ARC Training Centre for Advanced Technologies in Rail Track Infrastructure (ITTC-Rail), University of Wollongong Australia, Wollongong, NSW 2522, Australia and impact loads, while protecting the formation soils from being subjected to shear failure and excessive settlements $[29,54,59]$. The ballast layer consists of natural or crushed granular material with a typical thickness of $250-350 \mathrm{~mm}$ that is placed beneath the track superstructure and above the sub-ballast and sub-grade providing structural support against the stresses imposed by moving wheel loads. Conventionally, crushed, angular hard stones and rockfill, uniformly graded, free of contaminants such as infiltrated soil, and not susceptible to pozzolanic or cementing action are considered to be suitable ballast materials [19, 40, 61, 62].

During train operations, ballast deteriorates due to the degradation of angular corners and sharp edges, intrusion of fines and mud-pumping from the underlying soft soil layers. In addition, impact forces generated by wheel and/or rail irregularities or imperfections or at transitions zones (e.g. bridge approaches and exits, road crossings) may exacerbate track deterioration initiating frequent maintenance cycles [9, $43,52]$. As a result, ballast assembly becomes degraded/ fouled and its grain angularity, overall strength and ability to drain off water are seriously compromised $[27,63,64,66]$. 
Such deterioration of ballast can lead to frequent and costly maintenance, especially as the heavy haul tracks are subjected to higher speeds and heavier axle loads [3, 29]. In this regard, the use of artificial inclusions including geogrids, geocomposites and recycled rubber sheets to mitigate the deformation and degradation of ballast has become popular in recent years [5, 6, 8, 12, 46-48, 67], among others. Several studies have shown that the mechanical interlocking between geogrids and ballast particles can reduce the lateral displacements and breakage of ballast $[4,24,39]$. However, when the ballast is fouled, the interaction between the aggregates and geogrid reinforcement can decrease significantly [44].

Recently, the use of rubber energy-absorbing materials in rail tracks has drawn greater attention, because rubber has high damping properties that can reduce noise, vibration, and damage to the track components. Furthermore, these rubber products may be obtained from end-of-life tyres, which is economically attractive and environmentally friendly. There are direct ways of reducing the degradation of ballast using rubber materials: (i) rail pads (i.e. placed at the interfaces between rails and sleepers); (ii) under sleeper pads (i.e. placed at the sleeper/ballast interfaces); (iii) rubber mats installed beneath the ballast (shock mats); and (iv) ballast mixed with rubber crumbs or shreds $[17,41,60]$. The inclusion of rubber shock mats decreases the hard interface between the ballast aggregates and other track components, such as the sleepers or underlying formations, and allows the particles bedding into softer pads, thus enhancing the area of contact of the aggregates and minimising the inter-particle contact forces [42, 47, 51]. Moreover, indirect methods to reduce the degradation of ballast by using rubber products in the sub-ballast layer have also been proposed in recent times, such as replacing the traditional sub-ballast with an energy-absorbing layer composed of waste materials, including coal wash, steel furnace slag and rubber crumbs [28, 55], and using a capping layer confined with recycled rubber tyre cells [17]. In this paper, some of these methods involving the use of recycled rubber products in rail tracks will be presented and discussed.

Currently, there is a lack of comprehensive scientific evidence on the load-deformation responses and the associated degradation behaviour of ballast under dynamic train loading when geosynthetics and resilient rubber elements are placed in the track substructure. This paper reviews research work conducted at the UOW over the past decades including large-scale experimental testing, numerical modelling and field investigations to analyse track performance and the benefits of using artificial inclusions. The effect of rubber crumbs on the deformation behaviour, resilient and shear moduli, damping properties of waste materials to be used as sub-ballast is also described. An innovative method of confining the upper sub-ballast stratum with scrap rubber tyres for increased stability of the track substructure is introduced and validated through large-scale cyclic triaxial tests. The role of various types of geogrids in stabilising ballast is analysed based on the data of large-scale tests, drop-weight impact tests and discrete element modelling. Data obtained from field trials conducted on fully instrumented track sections at Bulli, north of Wollongong city, are presented and discussed.

\section{Laboratory study}

\section{Energy-absorbing layer for sub-ballast using waste materials}

\section{Materials and test program}

Three waste materials (i.e. coal wash, steel furnace slag and rubber crumbs) were combined to develop a synthetic energy-absorbing layer (SEAL) to replace traditional subballast as a 'capping' material underlying the ballast layer. Steel furnace slag (SFS) and coal wash (CW) consist of granular by-products supplied by Australian Steel Milling Services and Illawarra Coal. The rubber crumbs (RC) were derived from discarded waste tyres; three different sizes of RC (i.e. 0-2.3 mm; 0.3-3 $\mathrm{mm}$; and 1-7 $\mathrm{mm}$ ) were used, as shown by the particle size distributions (PSD) of the waste mixtures (Fig. 1). Based on the USCS (i.e. Unified Soil Classification System), SFS and CW are classified as well-graded gravels with silty sands and well-graded sands with gravels. The rubber crumbs can be classified as granulated rubbers [2].

To optimise the SFS + CW + RC mixtures as suitable sub-ballast, eight parameters were selected based on the existing criteria for traditional sub-ballast materials and

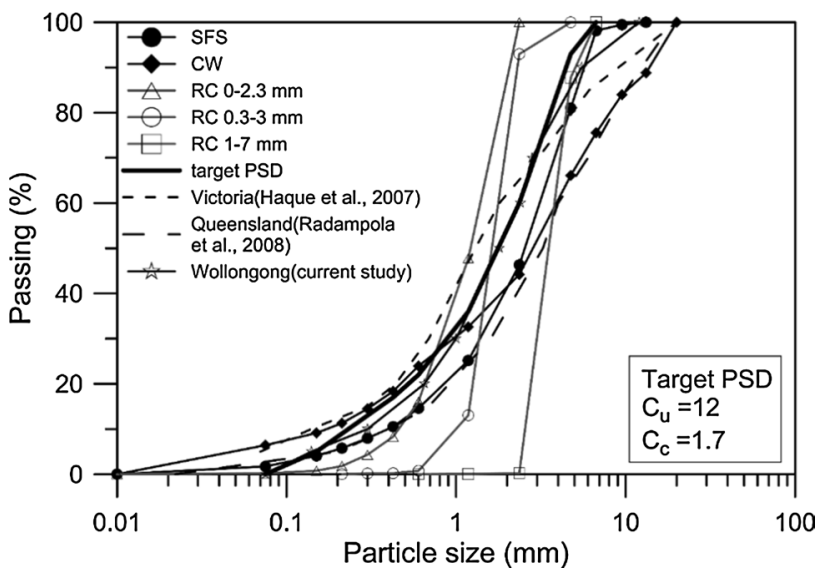

Fig. 1 Particle size distribution (PSD) curves of the waste materials and selected PSD for the waste matrix ([28]; with permission from ASCE) 
considering the geotechnical properties of these three waste mixtures (Fig. 2). First, the waste mixtures should fulfil the functions of the capping layer, and then, the adverse geotechnical characteristics of the waste materials (i.e. volumetric expansion of SFS, particle degradation of $\mathrm{CW}$, and high deformation and low strength of rubber crumbs) should be controlled to an acceptable range. Moreover, to develop an appropriate energy-absorbing capping layer that is superior to a traditional capping layer (usually composed of compacted sandy gravel), the waste mixtures should maintain increased ductility, i.e. sufficient energy-absorbing capacity during straining. Therefore, eight parameters were considered here, i.e. gradation, permeability, peak friction angle, swell pressure, breakage index (BI), axial strain under cyclic loading, resilient modulus and strain energy density $(E)$. The breakage index was first proposed by Indraratna et al. [15] and defined according to the initial and final PSD before and after the test. The strain energy density can be defined to be represented by the area underneath the shear stress-strain plots up to the peak stress point. The test program was proposed and executed accordingly to obtain the abovementioned parameters (Fig. 2) and included permeability tests, swell tests and consolidated triaxial tests under both static and cyclic loading conditions. In order to exclude any influence of particle gradation, the three waste mixtures had to be prepared according to the same gradation that was selected based on the traditional sub-ballast (capping) (Fig. 1). The RC content in the mixtures was limited to $40 \%$. The blending ratio of SFS/CW was set as 5:5, 7:3 and 9:1. All the specimens for the tests were blended at the optimum moisture content and compacted to $95 \%$ of their maximum dry unit weight to mimic a given field condition.

\section{The optimum mixture}

In the test program, all the $\mathrm{SFS}+\mathrm{CW}+\mathrm{RC}$ mixtures were prepared to the PSD that satisfies the gradation limits of conventional capping or sub-ballast material. Moreover, the permeability, energy-absorbing property and particle degradation characteristics of all the blended mixtures with $\mathrm{RC} \geq 10 \%$ and SFS/CW $\geq 5: 5$ were superior to the traditional sub-ballast [28]. However, a higher content of SFS causes an increased volumetric expansion, and the higher the $\mathrm{CW}$ proportion, the lower the shear strength, i.e. the blending ratio of SFS/CW is the main factor governing the shear strength and the swell potential of the matrix. Therefore, the optimum ratio of SFS/CW could be selected by taking into account the swell pressure and shear strength of $\mathrm{SFS}+\mathrm{CW}+\mathrm{RC}$ mixture having $10 \% \mathrm{RC}$, as shown in Fig. 3a. To ensure that the optimum mixture has a higher shear strength than conventional capping or sub-ballast and a lesser swell pressure compared to the typical loads applied to the capping layer, the waste mixtures were expected to satisfy $\emptyset_{\text {peak }}^{\prime} \geq 49^{\circ}$ [28] and $P_{\text {swell }}<30 \mathrm{kPa}$ [10]; thus, the ratio of $\mathrm{SFS} / \mathrm{CW}=7: 3$ could be regarded as the optimum ratio.

The optimal RC content was selected based on the parameters of breakage index, peak friction angle, resilient modulus, strain energy density, swell pressure and axial strains subject to cyclic loads (Fig. 3b-d), obtained from the test results of SFS $+\mathrm{CW}+\mathrm{RC}$ matrix with the optimal $\mathrm{SFS} / \mathrm{CW}=7: 3$. Figure $3 \mathrm{~b}$ shows that only mixtures with $R_{b}$ from 8 to $18.5 \%$ satisfy the required range based on particle breakage (BI $\leq 2 \%)$ and shear strength $\left(\emptyset_{\text {peak }} \geq 49^{\circ}\right)$. Based on the test results of resilient modulus, the optimal RC
Fig. 2 Parameters and test program used to optimise the $\mathrm{SFS}+\mathrm{CW}+\mathrm{RC}$ mixtures

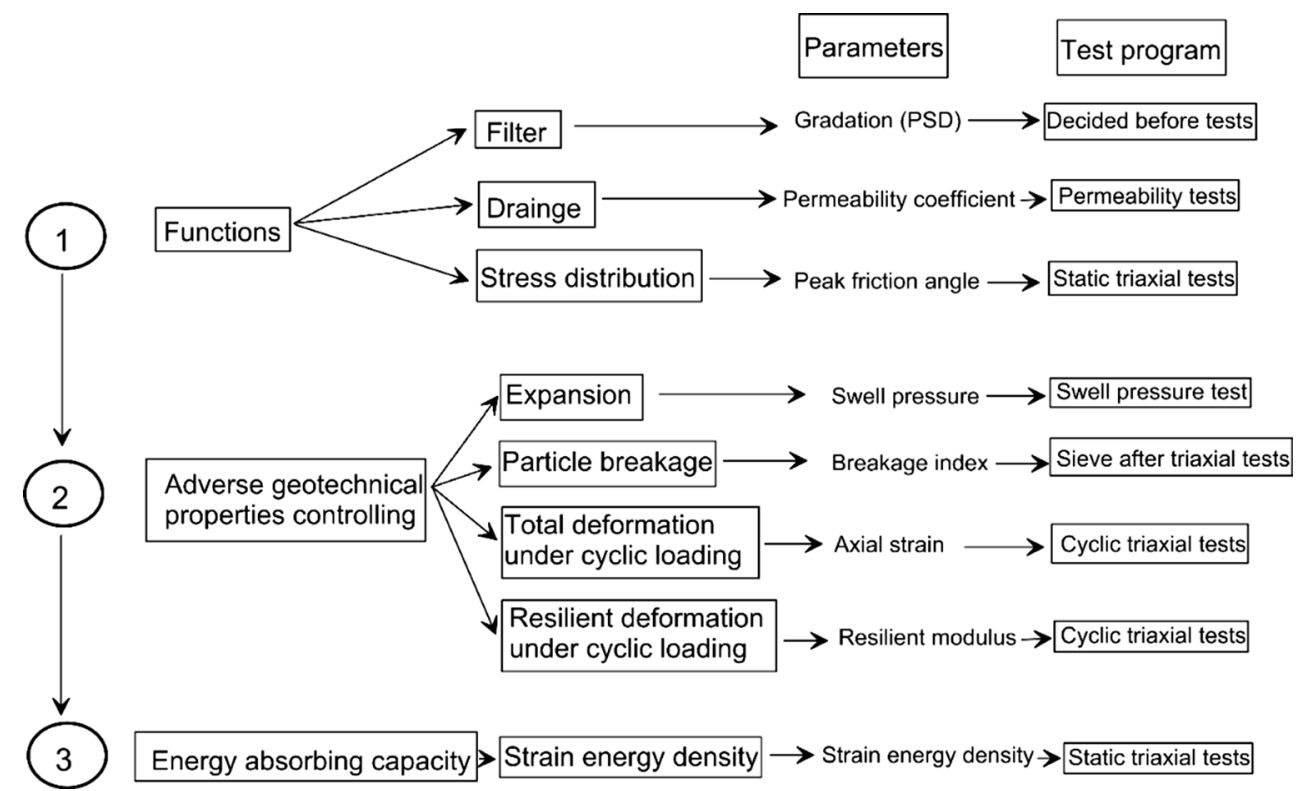




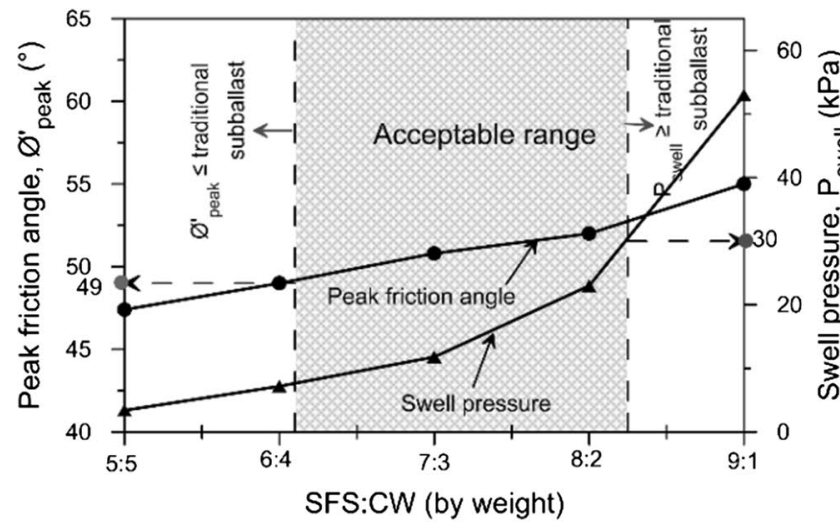

(a)

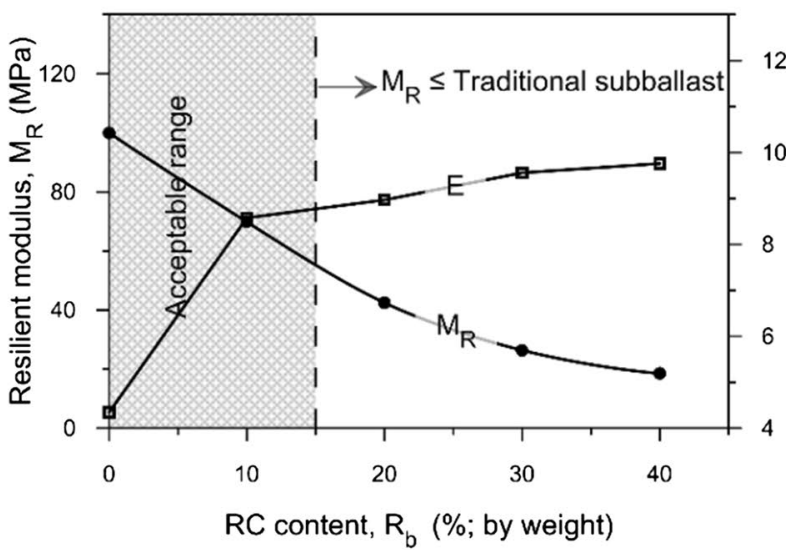

(c)

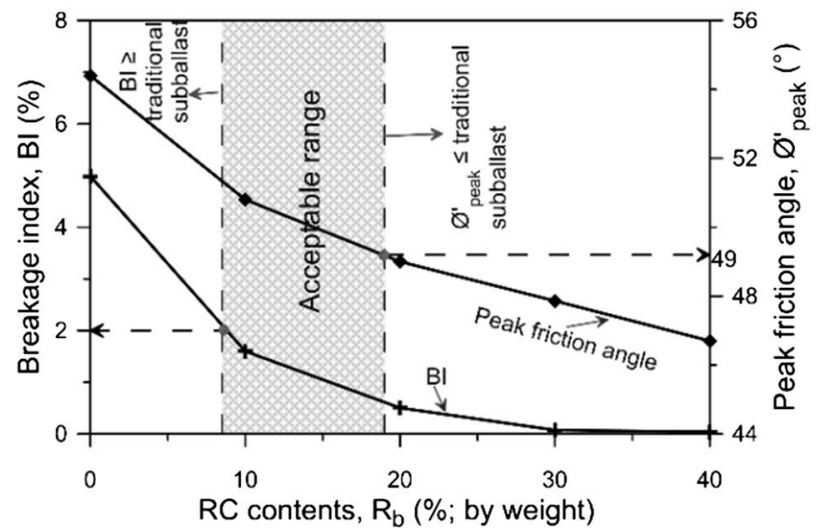

(b)
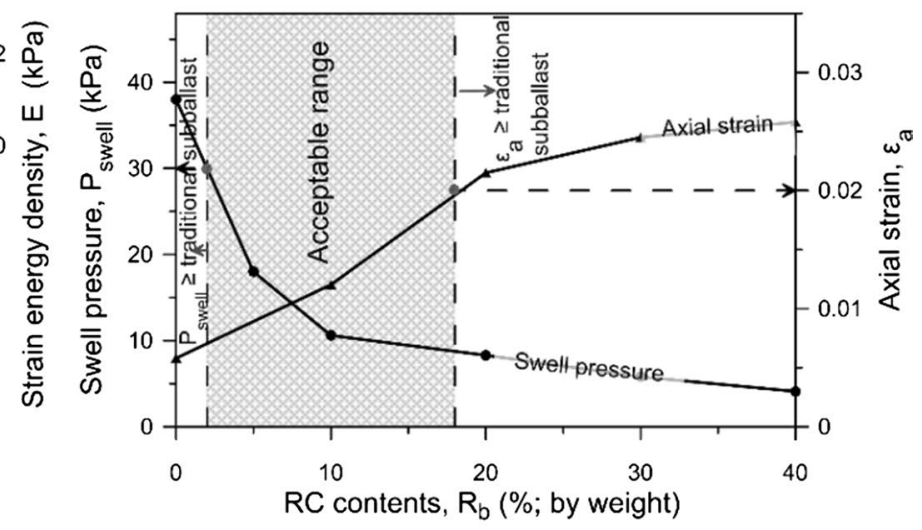

(d)

Fig. 3 a Optimising the blending ratio of SFS/CW, b-d optimising the RC content Data source: [28] and [55]; with permission from ASCE

content should less than 15\% (Fig. 3c), while Fig. 3d shows that only mixtures with $R_{b}$ from 2 to $18 \%$ satisfy the required range of axial strain under cyclic loading $(\leq 2 \%)$ and swell pressure $\left(P_{\text {swell }}<30 \mathrm{kPa}\right)$. Therefore, the combined acceptable range of rubber crumbs in the waste mixtures taking into account particle breakage, shear strength, axial strain, swell pressure and resilient modulus should be between 8 and $15 \%$. It is noteworthy that $10 \%$ of RC is sufficient to improve substantially the energy-absorbing capacity of the waste mixtures, without influencing significantly the axial displacement and associated shear strength in both static and cyclic loading conditions. In this context, $10 \%$ of RC can be taken as the optimum amount of RC; thence, the optimum mixture could be established as SFS63 + CW27 + RC10 (SFS/CW $=7: 3$ and $10 \% \mathrm{RC}$ ).

\section{Energy-absorbing analysis}

The energy-absorbing characteristics of the SFS + CW + RC mixtures were evaluated by the strain energy density and can also be related to particle breakage. Figure 4 a describes the strain energy density of the waste mixtures as well as the traditional sub-ballast. Note that the strain energy density of the waste matrix having rubber crumbs differs significantly from those without rubber crumbs, indicating the enhanced energy-absorbing ability of the matrix. As expected, the inclusion of $\mathrm{RC}$ could reduce the particle degradation of the waste mixture significantly (Fig. 4b). When RC content is more than $30 \%$, the particle breakage of the SFS + CW + RC mixtures becomes negligible. On the other hand, when RC content exceeds $10 \%$, the increase in the strain energy density is shown to be marginal. Therefore, $10 \% \mathrm{RC}$ is enough to increase the energy-absorbing capacity of the waste mixtures. It is assumed that if the total energy induced by the moving axle loads is a specific amount (kinetic energy), then by increasing the energy-absorbing capacity of the sub-ballast layer the energy transmitted to the ballast layer and substructure can be reduced; hence, less degradation of ballast is expected to occur.

Qi et al. [55] established an energy-consumption flowchart based on the comprehensive properties of $\mathrm{SFS}+\mathrm{CW}+\mathrm{RC}$ mixtures (Fig. 5). Generally, the energy absorbed by the energy-absorbing layer (EAL) would be converted to permanent deformation and/or dissipated by 
Fig. 4 Test results for

$\mathrm{SFS}+\mathrm{CW}+\mathrm{RC}$ matrix (after [15] and [56]): a strain energy density varying with effective confining pressure and $\mathbf{b}$ breakage index varying with $\mathrm{RC}$ content

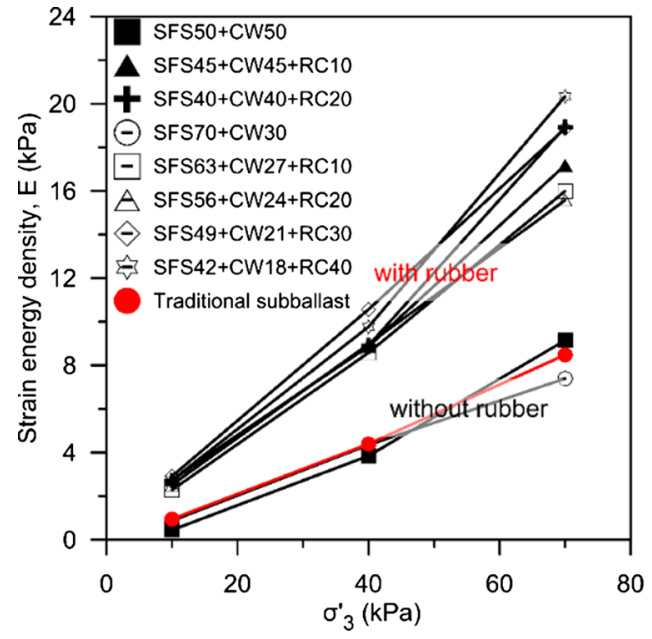

(a)

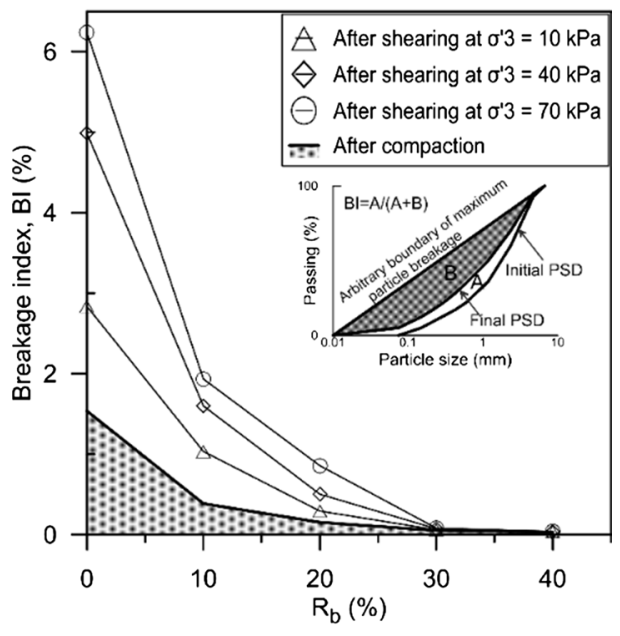

(b)

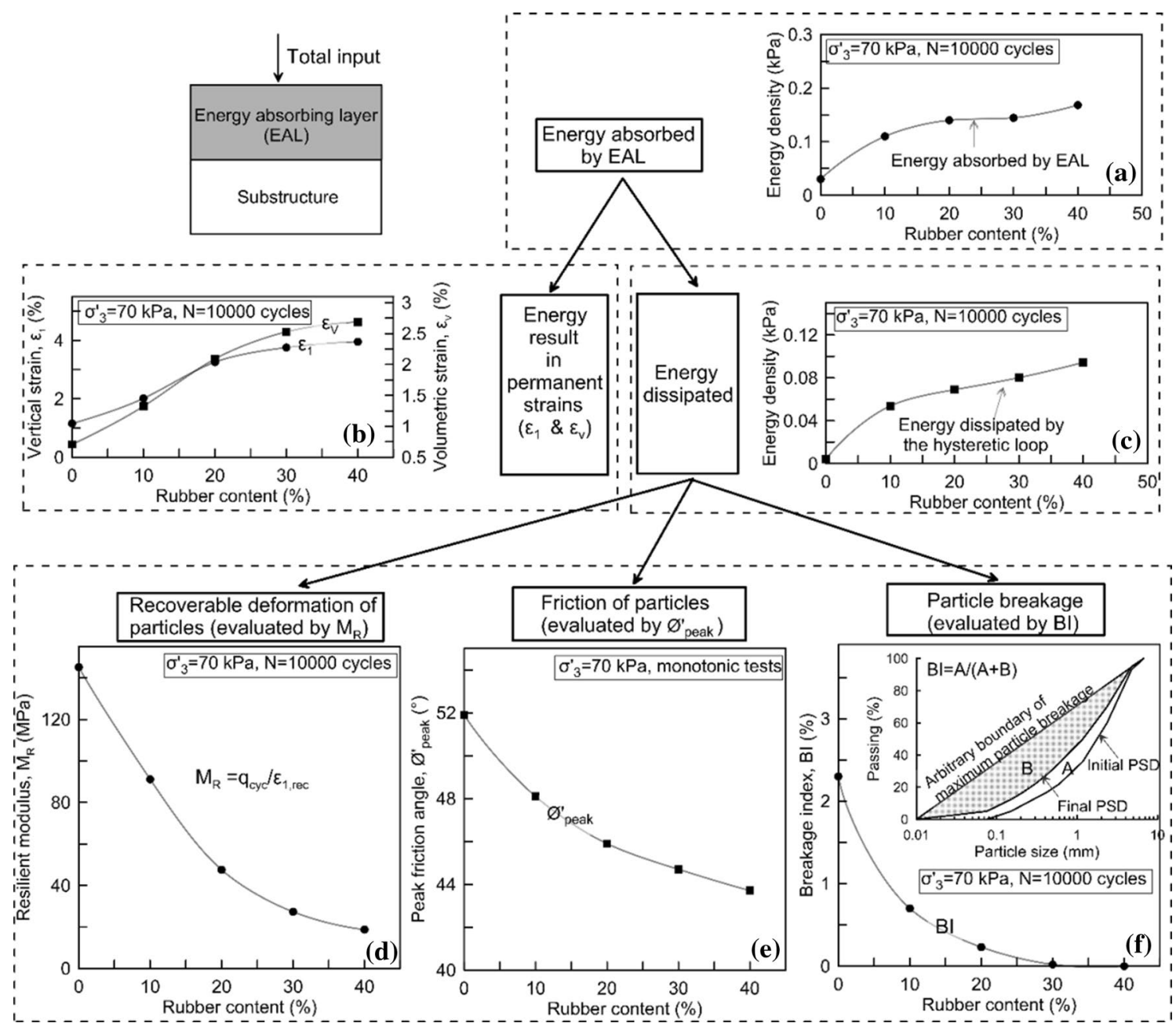

Fig. 5 Energy-consumption flowchart and comprehensive properties of SFS + CW + RC mixtures (SFS/CW $=7: 3$ ) having different RC contents at effective confining pressure $\sigma_{3}^{\prime}=70 \mathrm{kPa}$ and at loading cycles $N=10,000$ ([55]; with permission from ASCE) 
heat and particle breakage. The dissipated energy represented by the area of the hysteresis loop is due to: (a) the recoverable deformation of particles, (b) the friction of particles and (c) particle breakage [34, 35, 68]. The recoverable deformation is reflected by the value of the resilient modulus $M_{R}$. It should be noted that the rise in the dissipated energy mainly results from an increase in recoverable deformation $\left(M_{R}\right.$ decreases, Fig. 5 d) as the shear strength (Fig. 5e) and particle breakage (Fig. 5f) decrease with the inclusion of $\mathrm{RC}$ in the $\mathrm{SFS}+\mathrm{CW}+\mathrm{RC}$ mixtures. It is found that when more $\mathrm{RC}$ is added into the waste mixtures, the energy absorbed by the EAL increases as the area of the shear stress-shear strain triangle increases (Fig. 5a), indicating that less energy will be transmitted to the substructure or the ballast layer. However, the energy transmitted to ballast layer results in its irrecoverable plastic strains (Fig. 5b) and the dissipated energy increases (Fig. 5c). Therefore, it can be seen that increased content of rubber ensures the EAL ( $\mathrm{SFS}+\mathrm{CW}+\mathrm{RC}$ mixtures) to have a greater energy-absorbing capacity (more ductile) with less particle breakage, but having higher deformation, lower resilient modulus and reduced shear strength. Note that $10 \%$ of RC already has a promising energy-absorbing capacity, and less particle breakage than the mixtures without rubber, while tolerating an acceptable reduction in shear modulus and a small increase in strains. Therefore, the waste mixtures with $\mathrm{SFS} / \mathrm{CW}=7: 3$ and $10 \% \mathrm{RC}$ are further validated as the optimum energy-absorbing layer for sub-ballast.

\section{Use of waste tyres to improve track performance}

\section{Materials and test program}

A novel method of confining the upper sub-ballast layer (capping layer) with energy-absorbing rubber tyre cells to provide increased stability and resiliency to the track substructure was proposed by Indraratna et al. [26]. To examine the performance of the capping layer confined with the tyre cell, cyclic loading tests were carried out using the largescale process simulation prismoidal apparatus (PSPTA) developed at the University of Wollongong, Australia. The PSPTA has a cell area of $600 \times 800 \mathrm{~mm}$ and $600 \mathrm{~mm}$ high representing a simplified unit cell from the track foundation (Fig. 6a, b). To simulate the field conditions of the track, three layers of materials were placed in the PSPTA cell. The bottom layer was a 50-mm-thick compacted rockfill base that can simulate a typical structural fill, over which a $200-\mathrm{mm}$ thick capping layer was placed (Fig. 6b). Two types of compacted aggregates (i.e. crushed basalt with size $=0.3-20 \mathrm{~mm}$ and spent ballast with size $=10-60 \mathrm{~mm}$ ) with and without tyre confinement were used as capping layer. The upper layer consisted of fresh ballast. The cyclic loading tests were carried out under a frequency of $15 \mathrm{~Hz}$ to simulate a train
Fig. 6 a Track foundation formations, b schematic illustration of large-scale prismoidal triaxial rig and $\mathbf{c}$ details of cyclic loading ([26]; with permission from ASCE)

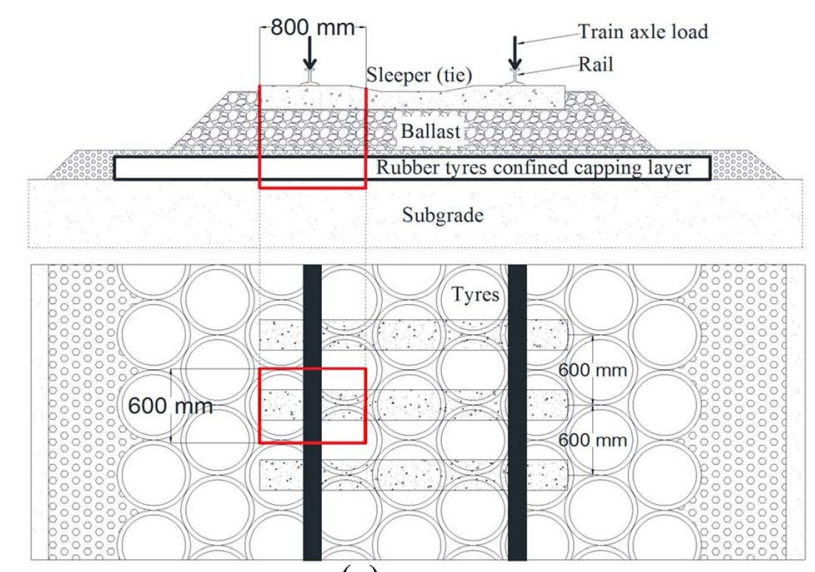

(a)

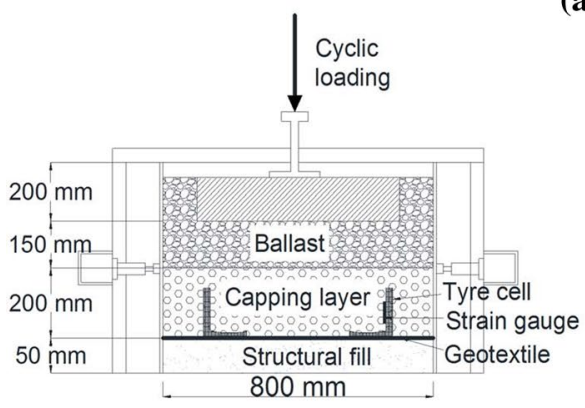

(b)

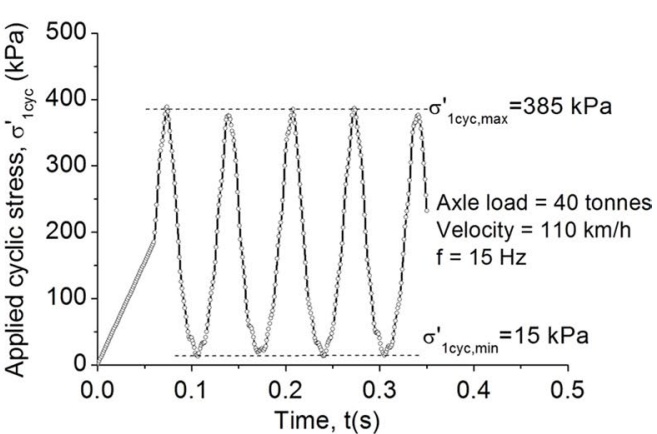

(c) 
operating at a speed of approximately $110 \mathrm{~km} / \mathrm{h}$ [25]. The details of the cyclic loading conditions are shown in Fig. 6c. $\sigma_{1 \text { cyc,max }}^{\prime}=385 \mathrm{kPa}$ and $\sigma_{1 \mathrm{cyc}, \text { min }}^{\prime}=15 \mathrm{kPa}$ were used to represent the maximum and minimum vertical stresses generated by a train having an axle load of 40 tonnes [31].

\section{Energy dissipation analysis}

Damping property which reflects the efficiency of dissipation of energy can be evaluated through the hysteresis response under cyclic loading and unloading, and it is a very important parameter for visco-elastic materials such as ballast. Intuitively, the inclusion of rubber tyre could improve the damping property of the system. Figure 7 a shows the hysteresis loops obtained at selected load cycles $(N)$, and the corresponding stress-strain curves are used to calculate the damping ratio $(D)$ and the dissipated strain energy $\left(E_{d}\right)$. A typical hysteresis loop is shown in Fig. 7b, where the equations to determine the damping ratio and the dissipated strain energy are provided. The damping ratio and the dissipated energy of the crushed basalt and spent ballast

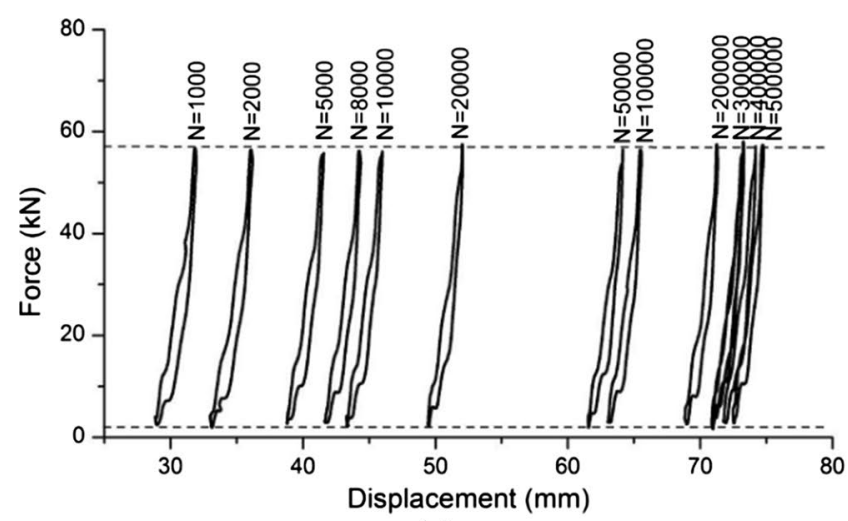

(a)

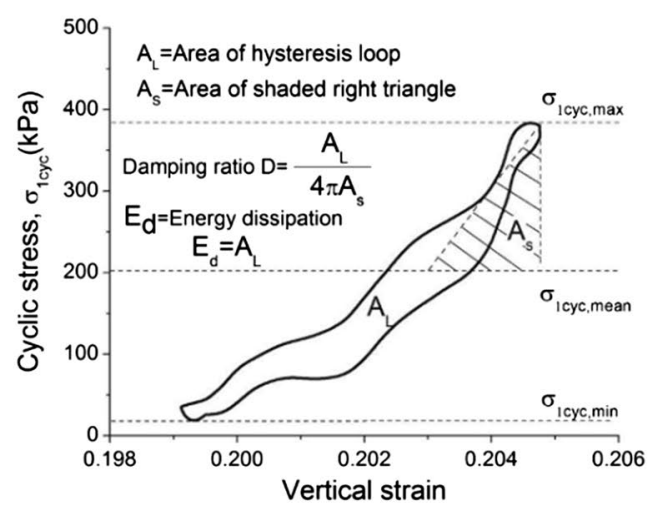

(b)

Fig. 7 a Hysteresis loops obtained from the cyclic loading test, b typical hysteresis loop showing the definition of damping ratio and energy dissipation $(N=500,000)$ and $\mathbf{c}$ variation of the damping ratio with and without tyre are shown in Fig. 7c. It is noted that the inclusion of rubber tyre enhances the damping properties of the system, and accordingly, the dissipated energy also increases. For $N<10,000$, both $D$ and $E_{d}$ decrease with increasing number of loading cycles due to the high dissipation of energy by plastic sliding and particle breakage, but then the values of $D$ and $E_{d}$ become almost constant because of the stabilisation and densification of the granular mass. This is an important finding since the increase in energy dissipation can reduce the deterioration of track elements, hence contributing to an important reduction in the cost of maintenance operations.

\section{The role of recycled tyres on ballast degradation}

It is reported that ballast could undergo significant changes during long-term service attributed to repeated cyclic and impact wheel loading [18]. To determine the particle breakage and the degradation mode of ballast, the fresh ballast directly under the sleeper (tie) was painted white (Fig. 8a). Three different modes of ballast degradation were found, i.e. the attrition of asperities, particle splitting and corner

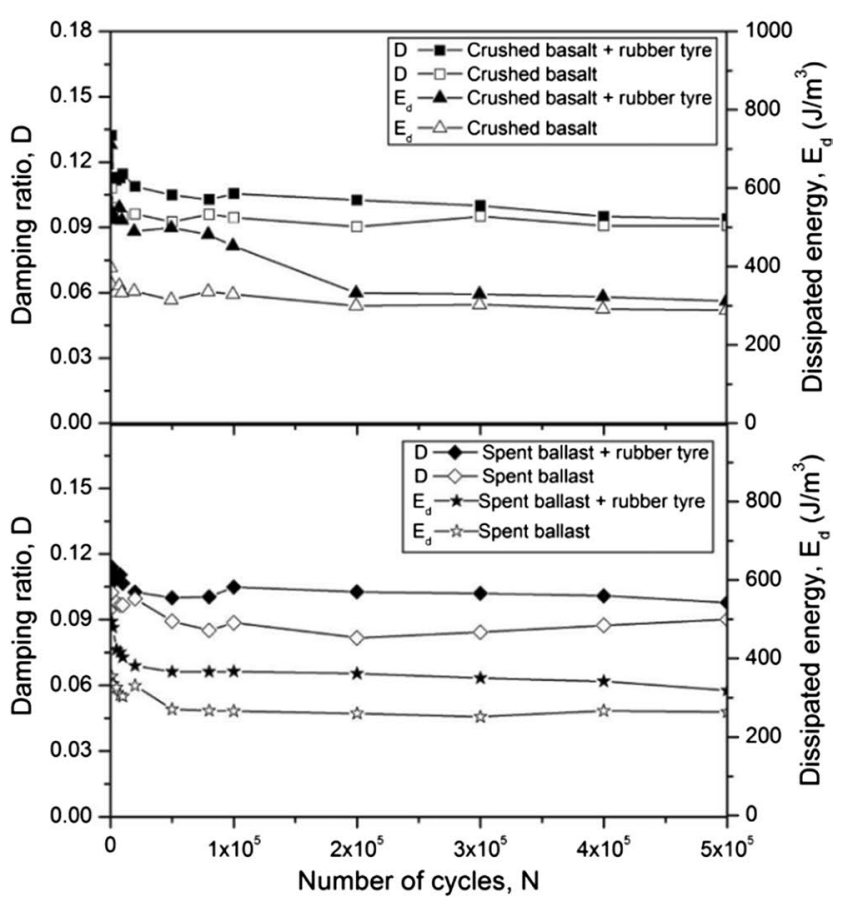

(c)

and dissipated energy with number of cycles for different test conditions ([26]; with permission from ASCE) 
Fig. 8 a Fresh ballast before cyclic loading test, $\mathbf{b}, \mathbf{c}$ particle degradation modes of ballast; d initial and final particle size distribution curves for crushed basalt and spent ballast ([26]; with permission from ASCE)

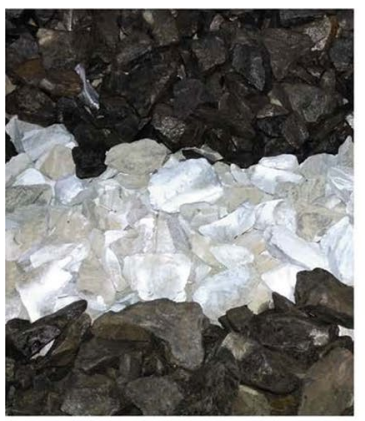

(a)

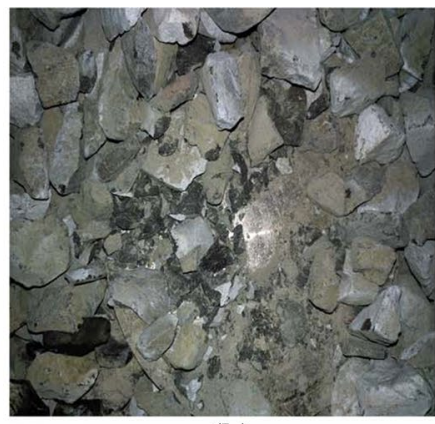

(b)

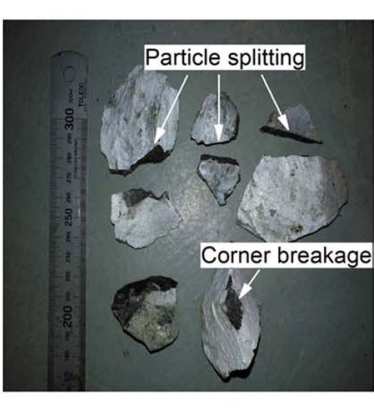

(c)

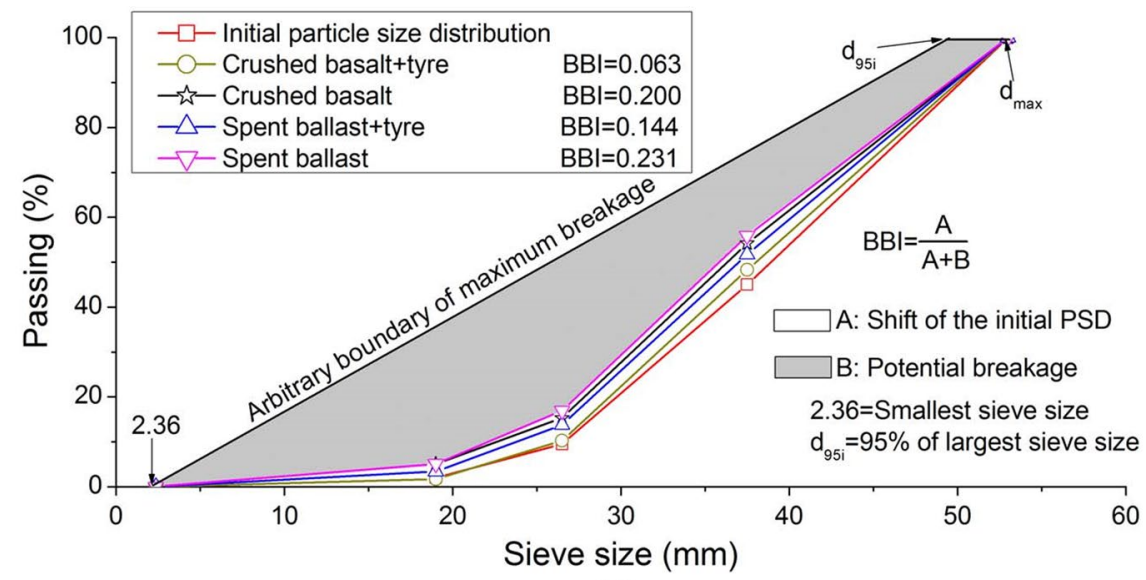

(d) breakage (Fig. 8b, c). The particle breakage was evaluated by the ballast breakage index (BBI; [15]), as shown in Fig. 8d. The PSD curves and the BBI values for crushed basalt and spent ballast with and without tyre are presented in Fig. 8d. It can be seen that the greatest change in the size of ballast occurred in the $37.5-\mathrm{mm}$ sieve. The crushed basalt or spent ballast with tyre has a lower BBI than those without tyre, indicating that the inclusion of tyre cell can indeed reduce the degradation of ballast because of the high efficiency in energy dissipation. This suggests that the durability of the overall track system could be improved by the use of rubber tyres.

\section{Geosynthetics-ballast interface}

The direct shear box used in this study consists of a $300 \mathrm{~mm} \times 300 \mathrm{~mm}$ by $200 \mathrm{~mm}$ high metal box (Fig. 9). The ballast obtained from south of Wollongong City was washed and sieved according to Australia Standards AS 2758.7 [1]. Coal fines were considered as fouling agents, and the VCI (i.e. void contamination index) was employed to quantify the degree of fouling. Direct shear tests were performed for both fresh and fouled ballast reinforced by a $40 \mathrm{~mm} \times 40 \mathrm{~mm}$ geogrid to a lateral shearing movement of $\Delta h=37 \mathrm{~mm}$. Detailed measured data were presented earlier by Indraratna et al. [27]. The test data showed that the shear strength (i.e. peak shear stress) of ballast increases with the increasing normal stresses and then it decreases with an increasing amount of fouling (i.e. increased $V C I$ ). Strain softening and volumetric expansion were observed in all the tests, where for larger normal stress, $\sigma_{n}$, higher shear strength and smaller volumetric dilations were measured. Tutumluer et al. [66] observed identical shear stress-strain responses during their laboratory tests. Figure 10 shows the variations of normalised peak shear stresses $\left(\tau_{p} / \sigma_{n}\right)$ and friction angles $(\phi)$ for both fresh and fouled (contaminated) ballast. It can clearly be seen that the coal fines steadily decrease the peak shear stress of reinforced and unreinforced ballast assemblies by coating the surfaces of the ballast aggregates, thus decreasing the friction and shear strengths of the composite assemblies [58]. The apparent friction angles measured in this study for unreinforced ballast assemblies range from $46^{\circ}$ to $65^{\circ}$ and are dependent upon the applied normal stresses and VCIs.

The influence of the geometry and aperture size of geogrids and confining pressure on the interface behaviour of the composite assembly has been examined by Indraratna et al. [14] and Ngo et al. [43]. Seven types of geogrids, namely G1 to G7 (Table 1) with square, rectangular, and triangular geometry and different aperture sizes were tested using the direct shear box. The effect of the applied normal stresses was measured, and the friction angle of ballast 
Fig. 9 Schematic of the shear box used for the experiment
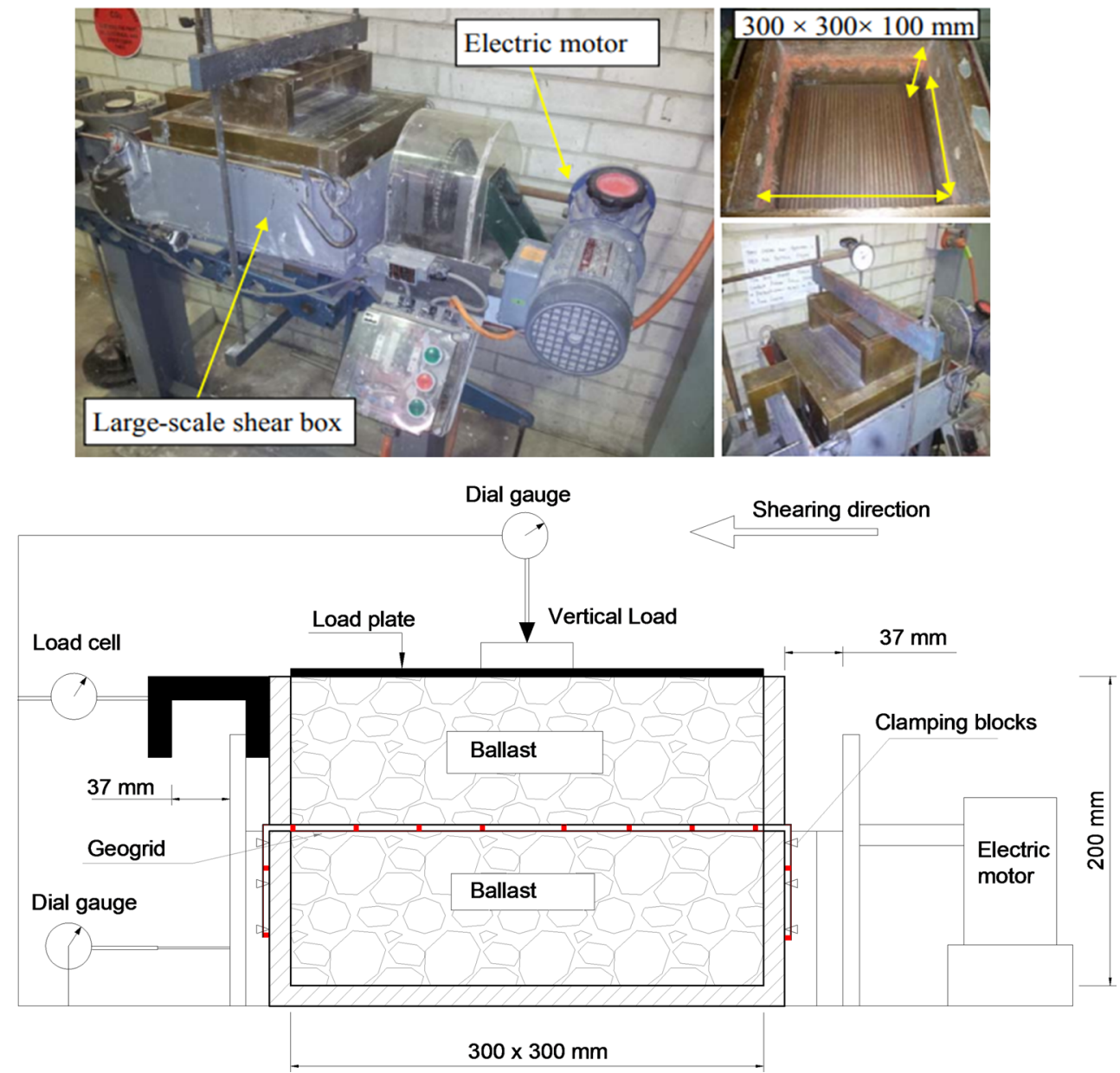

decreased from $64^{\circ}$ to $59^{\circ}$ when the normal stress increased from 26 to $61 \mathrm{kPa}$. It is generally accepted that the friction angle of granular materials decreases as the confinement increases, and similarly, the internal friction angle of ballast-geogrid interfaces also decreases with increased normal stresses; and this trend is similar to the unreinforced ballast $[37,47]$.

The actual improvement in the mechanical behaviour of ballast by the inclusion of geogrid reinforcement can be estimated using the interface efficiency factor $(\alpha)$, described as the ratio of the ballast-geogrid interface shear strength to the internal shear strength of ballast [14]:

$\alpha=\frac{\tan \delta}{\tan \varphi}$

where $\delta$ is the interface friction angle and $\varphi$ is the friction angle of the ballast. Note that the cohesion intercept for ballast materials is omitted.

The influence that the aperture size of geogrid has on the shear strength of the interface is shown in Fig. 11. Here, the value of $\alpha$ is a function of the $A / D_{50}$ ratio, where $\alpha$ increases with an increase in $A / D_{50}$ till it achieves the highest value of 1.16 at $A / D_{50}=1.21$. The value of $\alpha$ decreases towards unity when $A / D_{50}$ increases to 2.5 . The value of $\alpha<1$ implies that the geogrid does not interlock well with particles, whereas $\alpha>1$ shows an acceptable interlocking, which helps to increase the shear strength [14]. In other words, the $A / D_{50}$ value where $\alpha=1$ is the minimum condition needed to generate the benefits of geogrid reinforcement. Based on the variation of $\alpha$, an optimum interlock zone is defined where the interface efficiency factor is between 0.95 and 1.2. This study also indicates that the range of aperture sizes of geogrid to improve the ballast shear strength is $0.95-2.50 D_{50}$, and the optimum aperture size of geogrid is approximately $1.2-1.3 D_{50}$.

\section{Use of geogrids and rubber mats for improved ballast response under impact loading}

\section{Materials and test procedures}

The loads exerted by running trains usually form regular, harmonic stress forms. However, defects in the rails or wheels, including wheel flats, dipped rails, rail corrugation and defective rail welds may impart large impact forces onto the tracks. Impact loads can also be generated at transitions 
Fig. 10 Influence of VCI on the shear strength and friction angle: a no geogrid; $\mathbf{b}$ with geogrid Data source: [27]

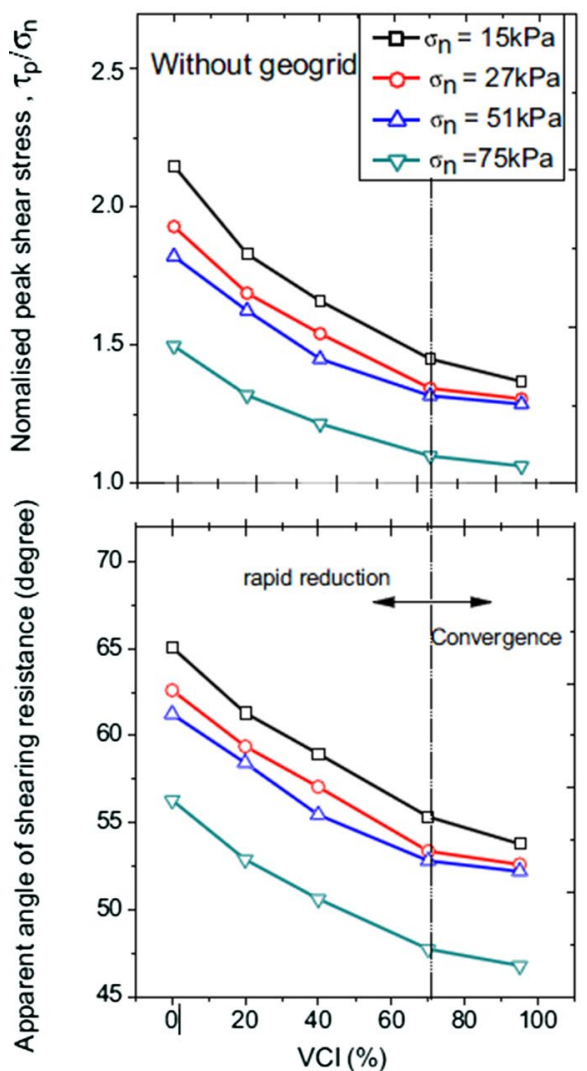

(a)

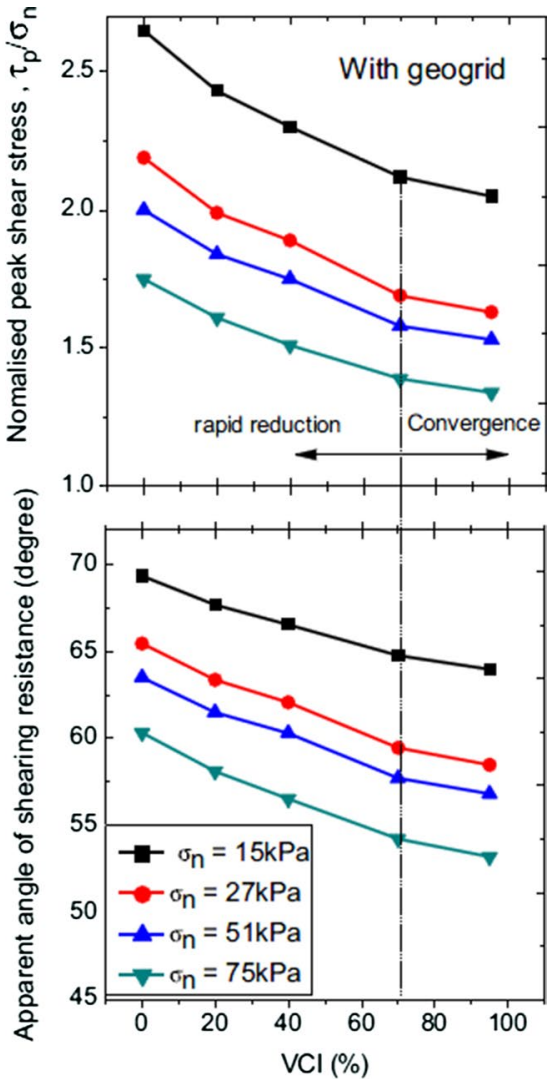

(b)
Table 1 Physical parameters of the tested geogrids [14]

\begin{tabular}{llll}
\hline Geogrid type & Aperture & $\begin{array}{l}\text { Aperture size } \\
(\mathrm{mm})\end{array}$ & $\begin{array}{l}\text { Tensile strength } \\
(\mathrm{kN} / \mathrm{m})\end{array}$ \\
\hline G1 & Square shape & $38 \times 38$ & 30 \\
G2 & Triangle shape & 36 & 19 \\
G3 & Square shape & $65 \times 65$ & 30 \\
G4 & Rectangle shape & $44 \times 42$ & 30 \\
G5 & Rectangle shape & $36 \times 24$ & 30 \\
G6 & Square shape & $33 \times 33$ & 40 \\
G7 & Rectangle shape & $70 \times 110$ & 20 \\
\hline
\end{tabular}

zones having different track stiffness (e.g. bridges, tunnels and road crossings) which exacerbates the deterioration of the track elements and implies the need for more frequent maintenance operations [9, 13, 16, 18, 43, 52]. Furthermore, with the significant increase in axle loads and train speeds, the vibrations attributed to wheel and rail imperfections are further intensified and the safe operation of trains can be compromised, which is why the application of polymeric inclusions, such as geogrids and energy-absorbing rubber sheets in rail tracks, has raised increasing attention in recent years.

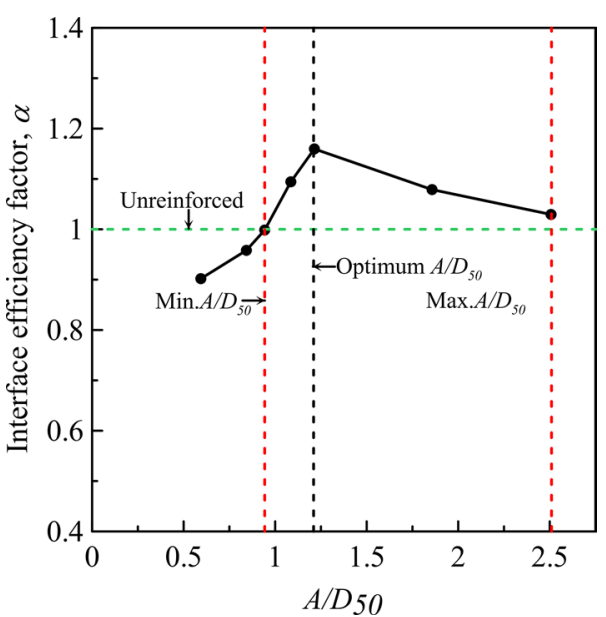

Fig. 11 Evolution of the interface efficiency factor $(\alpha)$ with $A / D_{50}$ (after [14]; with permission from ASTM)

In this context, a large drop-weight impact test equipment (Fig. 12a) developed in-house at the UOW [33] was used to analyse the behaviour of railway ballast reinforced by polypropylene biaxial geogrids (Fig. 12b) and resilient rubber mats (Fig. 12c) under repeated impact blows. The test rig is composed of a free-fall hammer (592 kg mass) 
Fig. 12 a Large-scale dropweight impact testing apparatus; b geogrid-reinforced ballast sample; c rubber mat sample and $\mathbf{d}$ sample ready for testing

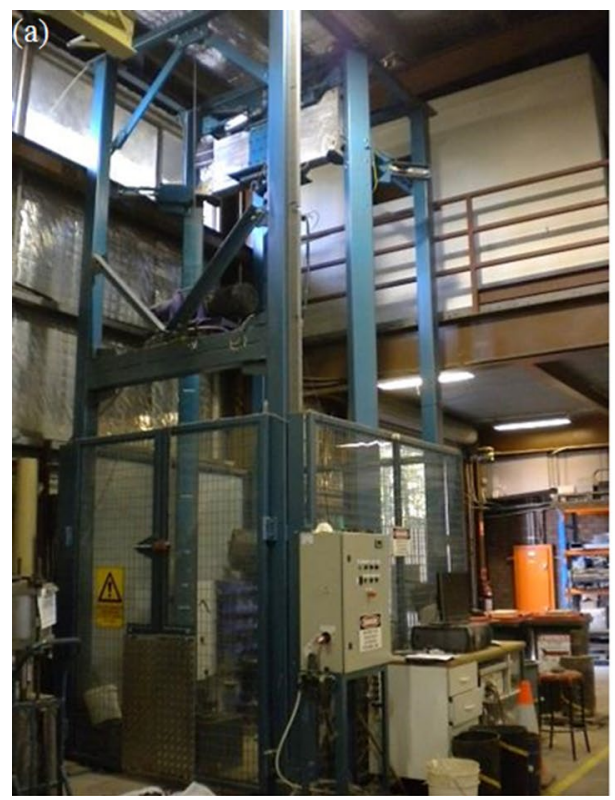

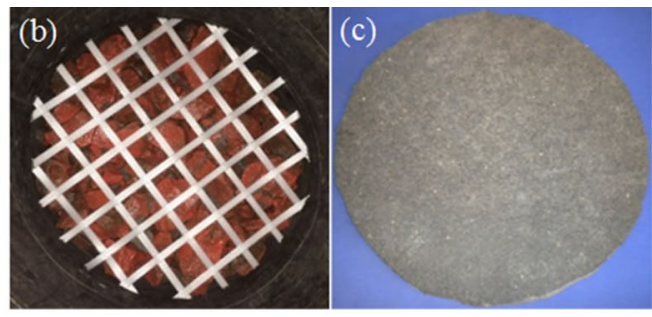

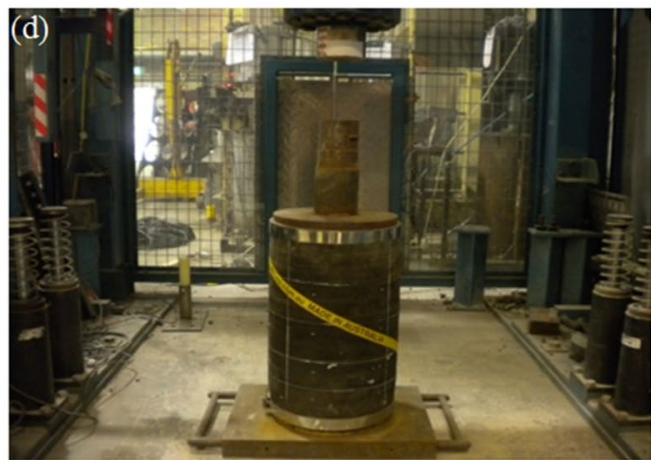

that may be released from a maximum height of approximately $6 \mathrm{~m}$, which allows the simulation of repeated impact loading, resembling actual track conditions. The drop hammer is fixed to rollers and guided by low-friction vertical rails connected to an isolated high-strength reinforced concrete floor. The apparatus can accommodate test specimens within a working area of $1800 \times 1500 \mathrm{~mm}$. The transient impact forces are monitored by a dynamic load cell (capacity of $1200 \mathrm{kN}$ ) attached to the hammer and connected to an automatic data acquisition system, whereas the permanent settlement and radial displacements of the test samples are obtained by manual measurement after every drop.

Latite basalt (volcanic) as rail ballast was sourced from a local quarry located south of Wollongong City, following the gradation recommended by AS 2758.7 (2015). To resemble a relatively low confinement as typically encountered in the field, the granular materials were restrained using a rubber membrane (300 $\mathrm{mm}$ inner diameter) thick enough to avoid piercing by ballast particles under severe impact loads (Fig. 12d). First, a 150-mm-thick soil layer consisting of a mixture of sand and gravel (sub-ballast layer) was compacted in dry conditions to the unit weight of $18.8 \mathrm{kN} /$ $\mathrm{m}^{3}$. The ballast aggregates were compacted above the subballast layer to a unit weight of $15.3 \mathrm{kN} / \mathrm{m}^{3}$, using a rubberpadded electric vibratory hammer. To evaluate the ballast breakage with depth after the tests, the ballast samples were divided into three 100-mm-thick layers and distinguished by colour coding. In practice, 10-60-mm-thick rubber mat layers are often used in railway tracks either as ballast mats or under sleeper pads. Taking this into account, three layers of 10-mm-thick rubber mats manufactured from recycled rubber granulates were used either below or above the ballast layer. To analyse the effect of combining resilient rubber mats and geogrids, additional tests were conducted in which the rubber mats were placed underneath the ballast and a polypropylene biaxial geogrid (composed of flat bars with welded junctions and 31-mm square apertures) was installed inside the ballast mass, at $100 \mathrm{~mm}$ distance from the base.

The free-fall hammer was raised to the selected drop height $(150 \mathrm{~mm})$ and dropped by an electronic-controller system. The drop height was defined so as to achieve dynamic stress values characteristic of common wheel flats and dipped rail joints in the field [23, 32]. The tests were discontinued after twelve blows due to the attenuation of permanent deformations of the ballast. To assess the degree of particle breakage after the tests, the ballast layers were sieved and the shift in gradation was determined. The breakage was then estimated based on the ballast breakage index (BBI) proposed earlier by Indraratna et al. [15]. By comparing the results obtained for both reinforced and unreinforced ballast samples, the role of polymeric inclusions such as geogrids and resilient rubber mats in reducing the magnitude of transient impact forces and associated ballast deformation and degradation could be evaluated in detail.

\section{The role of artificial inclusions in improving ballast behaviour under impact loading}

Figure 13a, b shows typical impact force-time histories recorded during a single impact blow (1st and 12th drops of the free-fall hammer, respectively) in the test conducted on an unreinforced ballast specimen. Two distinct types of force peaks were obtained, namely multiple sharp peaks followed by a single peak of smaller magnitude, which prevailed over a longer duration. Jenkins et al. [32] nominated these forces as $P_{1}$ and $P_{2}$, respectively. $P_{1}$ forces represent 


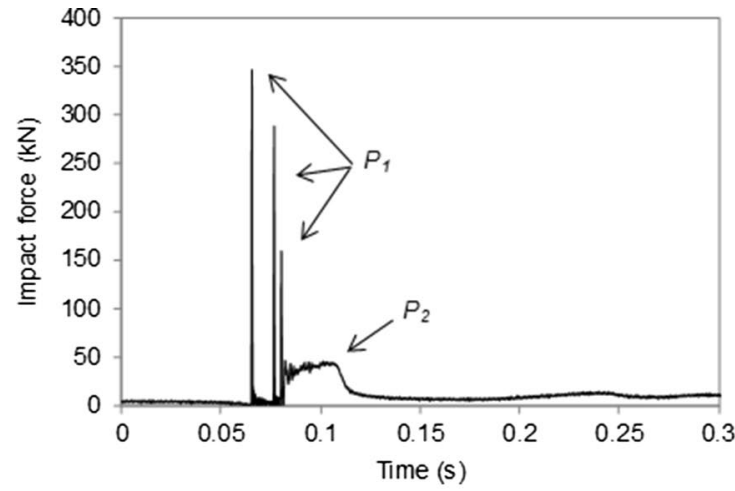

(a)

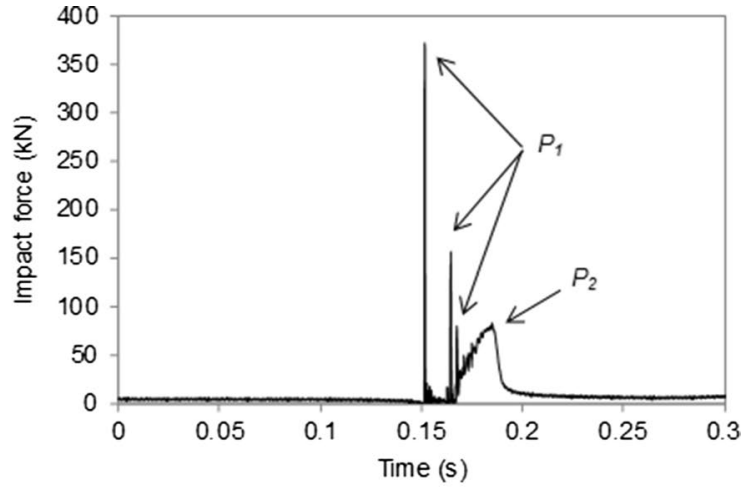

(b)

Fig. 13 Typical impact force responses under a single impact blow (unreinforced sample): a blow 1 and $\mathbf{b}$ blow 12

a quasi-instantaneous response of the test specimen to the impact load, and the multiple $P_{1}$ peaks occur due to the rebound of the drop hammer. These forces are caused by the inertia of the top plate resisting the descendent movement of the hammer and the compression of the contact area between the hammer and the specimen top plate. The effect of $P_{1}$ type forces is usually filtered out by the load assembly, and thus, they would not directly affect ballast degradation [11]. Conversely, the forces $P_{2}$ are associated with the mechanical resistance of ballast to impact loading, which leads to its compression. Therefore, $P_{2}$ forces are of great importance in the analysis of track degradation (e.g. [57]).

Figure 14 presents the evolution of the maximum $P_{1}$ and $P_{2}$ forces recorded over the repeated impact blows in the tests carried out on an unreinforced ballast sample, samples with rubber mats placed either at the bottom or top of the ballast layer, and a sample with rubber mats beneath the ballast layer and a geogrid at $100 \mathrm{~mm}$ height (from the ballast base). While the $P_{1}$ peak forces did not significantly change along the successive blows (Fig. 14a), the impact forces $P_{2}$ increased progressively during the tests (Fig. 14b), which could be attributed to the densification of the ballast layer. In fact, with cumulative impacts, the ballast becomes denser due to the rearrangement and rupture of particles, which increases the inertial resistance inducing greater $P_{2}$ values. These results suggest that in a recently installed track, where the ballast particles are in a relatively loose state, the magnitude of the impact forces will be lower than in a heavily used rail track where the ballast is denser. Figure 14b also shows that the inclusion of rubber mats led to a significant reduction in the magnitude of the impact forces $P_{2}$, which is associated with the energy-absorbing capacity or damping characteristics of these materials, and this reduction tended to be slightly higher when the mats were placed on top of the ballast sample.

The permanent (i.e. irrecoverable) axial and radial strains of ballast over the number of blows for the aforementioned test conditions are plotted in Fig. 15a and b, respectively. As expected, ballast deformations increased progressively with the repeated hammer blows. The strain increments were more pronounced during the initial blows, which is related to the reorientation/rearrangement and breakage of aggregates

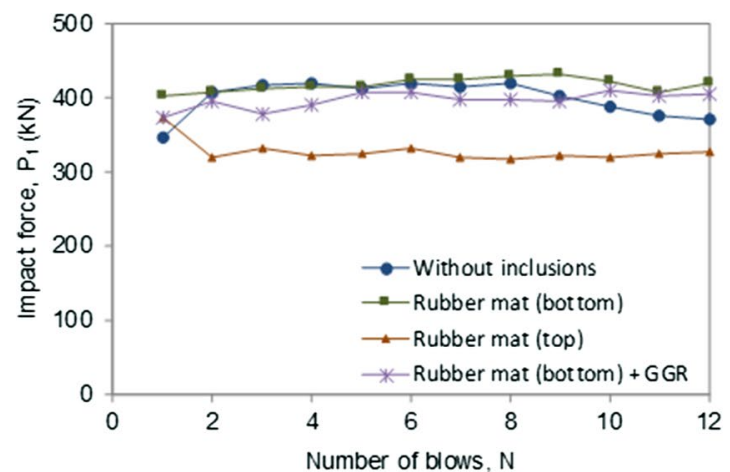

(a)

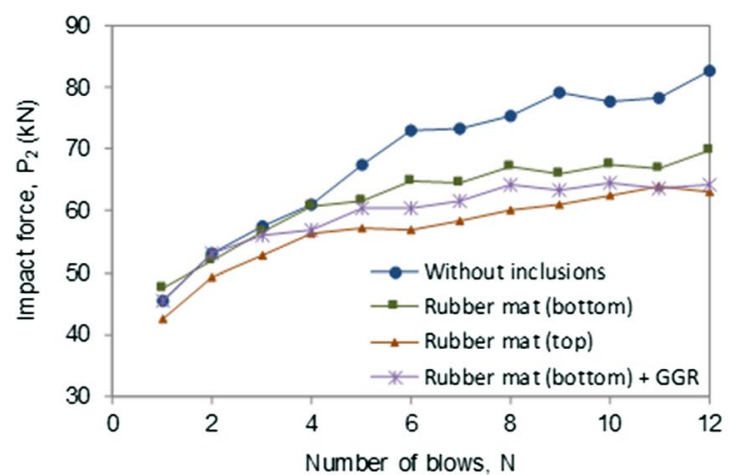

(b)

Fig. 14 Influence of rubber mat location and geogrid inclusion on the variation of impact forces with number of blows: $\mathbf{a} P_{1}$ force and $\mathbf{b} P_{2}$ force 


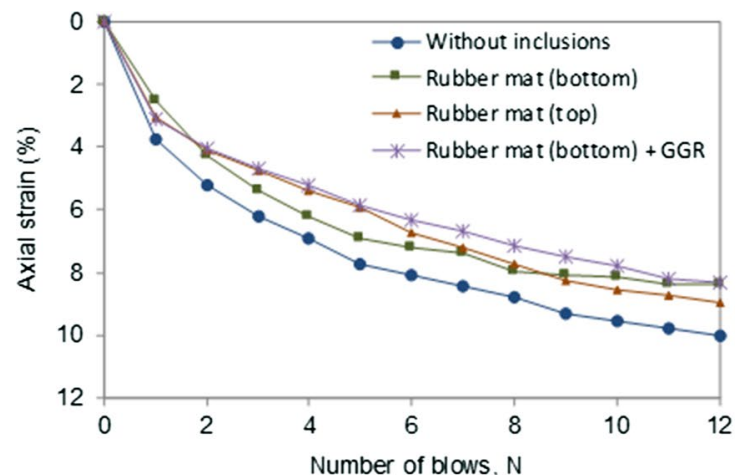

(a)

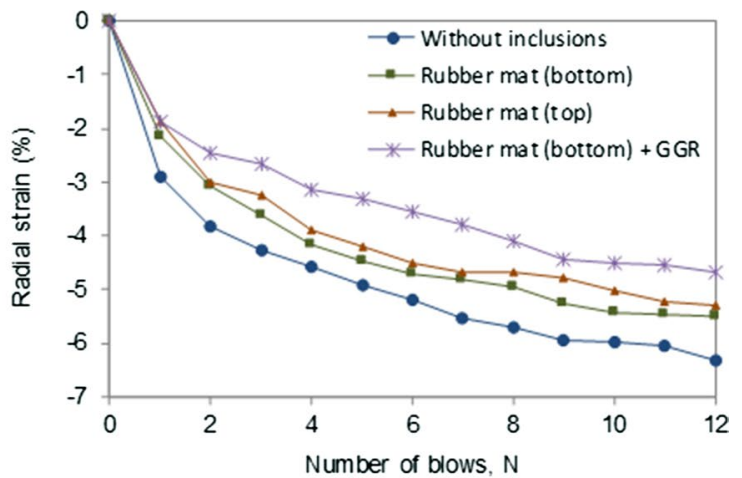

(b)

Fig. 15 Influence of rubber mat location and geogrid inclusion on the permanent strain response of ballast: a axial strains and $\mathbf{b}$ radial strains

and gradually reduced after a certain stage. It can also be observed that ballast deformations could be mitigated by the inclusion of rubber mats either below or above the ballast layer. Moreover, installing a rubber mat underneath the ballast and a geogrid at $100 \mathrm{~mm}$ height further enhanced the ballast deformation behaviour, which is associated with the interlocking of ballast aggregates within the geogrid apertures. This offers additional confinement to the ballast layer, hence contributing to a reduced extent of lateral spreading.

Following the method suggested by Indraratna et al. [15], the shift in the ballast particle size distribution was evaluated after the tests and the values of the ballast breakage index (BBI) were obtained. The average values of BBI for samples with rubber mats placed on bottom and top of the ballast mass were 0.148 and 0.097 , respectively. This suggests that, for relatively soft sub-grade conditions, the optimum location for the rubber mats for mitigating the impulse waves would be at the top surface of ballast mass, because the relatively soft sub-grade would act itself as a relatively flexible cushion.

\section{Computational modelling for ballasted rail track}

\section{Discrete element method (DEM)}

The distinct element modelling (DEM) was originally proposed by Cundall and Strack [7] and is widely applied to examine the mechanical response of granular assemblies. The DEM technique is often used to simulate the discrete nature of ballast aggregates, which consist of irregularly shaped particles subjected to static and dynamic loadings $[20,38,45,50,53,67]$. Particle displacements are calculated using the Newton's second law while the interaction among aggregates is determined using contact laws. The force vector, $\vec{F}$ representing the interactions among aggregates, is solved into normal force $\left(\vec{F}_{N}\right)$ and shear force components $\left(\vec{F}_{T}\right)$ accordingly at the contact plane:

$\vec{F}_{N}=K_{N} U^{n}$

$\delta \vec{F}_{T}=-K_{T} \cdot \delta U^{s}$

where $K_{N}$ and $K_{T}$ : normal and shear stiffness; $U^{n}$ : normal penetration between two aggregates; $\delta U^{s}$ : incremental shear displacement; and $\delta \vec{F}_{T}$ : incremental shear force.

The resistance moment $\vec{M}_{r}$ can also be used to simulate the restraint due to interlocking among aggregates; it is given by:

$\vec{M}_{r}=\left\{\begin{array}{lll}K_{r} \vec{\omega}_{r} & \text { if } & K_{r}\left\|\vec{\omega}_{r}\right\|<\left\|\vec{M}_{r}\right\|_{\lim } \\ \left\|\vec{M}_{r}\right\|_{\lim } \frac{\vec{\omega}_{r}}{\left\|\vec{\omega}_{r}\right\|} & \text { if } & K_{r}\left\|\vec{\omega}_{r}\right\| \geq\left\|\vec{M}_{r}\right\|_{\lim }\end{array}\right.$

where $K_{r}=\gamma_{r}\left(\frac{R_{A}+R_{B}}{2}\right)^{2}$; and $\left\|\vec{M}_{r}\right\|_{\text {lim }}=\eta_{r}\left\|\vec{F}_{r}\right\| \frac{R_{A}+R_{B}}{2} ; \vec{\omega}_{r}$ : a rolling angular vector that represents the changes in orientations of aggregates; $\eta_{r}$ : dimensionless coefficient; and $\gamma_{r}$ : coefficient of rolling resistance.

\section{Modelling the angularity of ballast aggregates}

Ballast aggregates of varied shapes and sizes can be represented by connecting many spheres together representing actual angularity and gradation [44]. The clump approach is used where aggregates within a clump can overlap provided that there are no contact forces among them. Clumps can behave as a rigid body [30, 49]. The required parameters for a clump include total mass, $m$; moment and product of inertia $I_{i i}$ and $I_{i j}$; locations of centre of clump mass, $x_{i}^{[G]}$. For instance, for a clump comprising $N_{p}$ particles, each has a mass of $m^{[p]}$, radius of $R^{[p]}$ and centre location of $x_{i}^{[p]}$; then, the mass properties are described by Itasca [30] as: 
$m=\sum_{p=1}^{N_{p}} m^{[p]}$

$x_{i}^{[G]}=\frac{1}{m} \sum_{p=1}^{N_{p}} m^{[p]} x_{i}^{[p]}$

$I_{i i}=\sum_{p=1}^{N_{p}}\left\{m^{[p]}\left(x_{j}^{[p]}-x_{j}^{[G]}\right)\left(x_{j}^{[p]}-x_{j}^{[G]}\right)+\frac{2}{5} m^{[p]} R^{[p]} R^{[p]}\right\}$

$I_{i j}=\sum_{p=1}^{N_{p}}\left\{m^{[p]}\left(x_{i}^{[p]}-x_{i}^{[G]}\right)\left(x_{j}^{[p]}-x_{j}^{[G]}\right)\right\} ; \quad(i \neq j)$

The motion of a clump is computed by forces and moments applying upon it, given by:

$F_{i}=m\left(\ddot{x}_{i}-g_{i}\right)$

The equation for rotational motion can be written in the matrix form [30]:

$\{M\}-\{W\}=[I]\{\alpha\}$

Fig. 16 DEM simulations: a simulated aggregates, $\mathbf{b}$ geogrid, c fresh ballast assembly and d fouled ballast assembly (@ $\mathrm{VCI}=40 \%$ ) where $\quad[M]=\left\{\begin{array}{l}M_{1} \\ M_{2} \\ M_{3}\end{array}\right\} ; \quad[I]=\left[\begin{array}{ccc}I_{11} & -I_{12}-I_{13} \\ -I_{21} & I_{22} & -I_{23} \\ -I_{31} & -I_{32} & I_{33}\end{array}\right]$;

$[\alpha]=\left\{\begin{array}{c}\alpha_{1} \\ \alpha_{2} \\ \alpha_{3}\end{array}\right\}=\left\{\begin{array}{c}\dot{\omega}_{1} \\ \dot{\omega}_{2} \\ \dot{\omega}_{3}\end{array}\right\}$

$[W]=\left\{\begin{array}{l}\omega_{2} \omega_{3}\left(I_{33}-I_{22}\right)+\omega_{3} \omega_{3} I_{23}-\omega_{2} \omega_{2} I_{32}-\omega_{1} \omega_{2} I_{31}+\omega_{1} \omega_{3} I_{21} \\ \omega_{3} \omega_{1}\left(I_{11}-I_{33}\right)+\omega_{1} \omega_{1} I_{31}-\omega_{3} \omega_{3} I_{13}-\omega_{2} \omega_{3} I_{12}+\omega_{2} \omega_{1} I_{32} \\ \omega_{1} \omega_{2}\left(I_{22}-I_{11}\right)+\omega_{2} \omega_{2} I_{12}-\omega_{1} \omega_{1} I_{21}-\omega_{3} \omega_{1} I_{23}+\omega_{3} \omega_{2} I_{13}\end{array}\right\}$

where $[M]$ : resultant moments; $\omega_{i}$ and $\dot{\omega}_{i}$ : angular velocities and angular accelerations.

\section{Modelling of large-scale direct shear tests}

Figure 16 demonstrates how the DEM is applied to simulate geogrid-stabilised ballast in the direct shear tests. The model dimensions are identical to those of the actual experiments. Ballast aggregates of various angularities are modelled by connecting many balls together representing actual ballast angularity (Fig. 16a). This approach is commonly adopted to model ballast grains [36, 39, 46-48], which are then generated at different places within the shear box.

A biaxial geogrid having $40-\mathrm{mm}$ square apertures is simulated by connecting many small balls together where the geometry and aperture replicates the geogrid tested in the

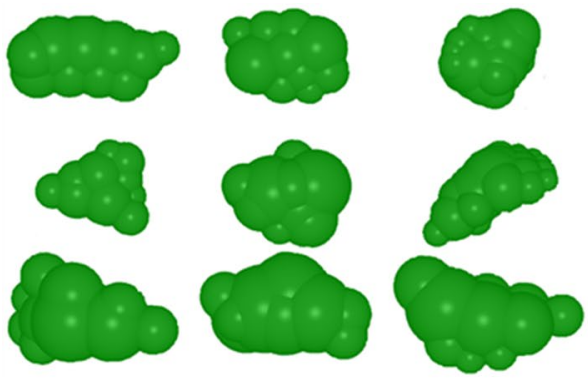

(a)

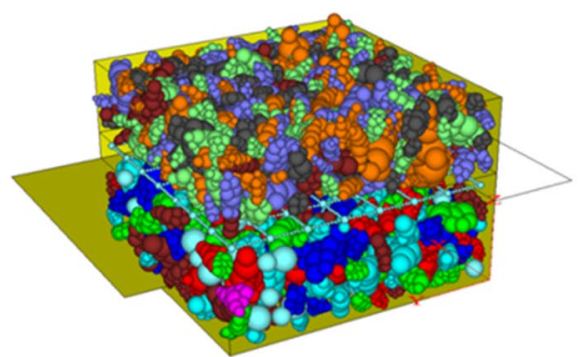

(c)

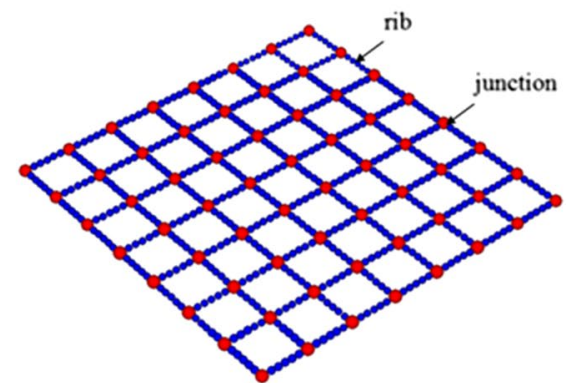

(b)

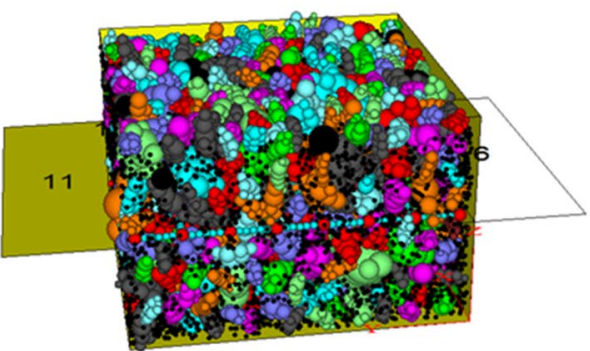

(d) 
Table 2 Micromechanical input parameters of geogrids, ballast and fouling [20]

\begin{tabular}{llll}
\hline Input parameters & Ballast grains & Fouling & Geogrid \\
\hline Density of grains $\left(\mathrm{kg} / \mathrm{m}^{3}\right)$ & 2700 & 800 & 800 \\
Friction coefficients & 0.8 & 0.2 & 0.5 \\
Stiffness of contact normal, $k_{n}(\mathrm{~N} / \mathrm{m})$ & $0.52 \times 10^{8}$ & $1.27 \times 10^{4}$ & $1.77 \times 10^{7}$ \\
Stiffness of contact shear, $k_{s}(\mathrm{~N} / \mathrm{m})$ & $0.52 \times 10^{8}$ & $1.27 \times 10^{4}$ & $0.88 \times 10^{7}$ \\
Normal stiffness of wall-aggregate $(\mathrm{N} / \mathrm{m})$ & $1 \times 10^{8}$ & $1 \times 10^{8}$ & $1 \times 10^{8}$ \\
Shear stiffness of wall-aggregate $(\mathrm{N} / \mathrm{m})$ & $1 \times 10^{8}$ & $1 \times 10^{8}$ & $1 \times 10^{8}$ \\
Multiplier for parallel bond radii, $r_{p}$ & & & 0.5 \\
Normal stiffness of parallel bonds, $k_{n p}(\mathrm{kPa} / \mathrm{m})$ & & & $5.68 \times 10^{8}$ \\
Shear stiffness of parallel bonds, $k_{s p}(\mathrm{kPa} / \mathrm{m})$ & & & $5.68 \times 10^{8}$ \\
Normal strength of parallel bonds, $\sigma_{n p}(\mathrm{MPa})$ & & & 456 \\
Shear strength of parallel bonds, $\sigma_{s p}(\mathrm{MPa})$ & & 456 \\
\hline
\end{tabular}

laboratory, as illustrated in Fig. 16b. The input micromechanical parameters adopted to simulate the ballast, geogrid and fouling materials are presented in Table 2 [20]. To quantify the level of ballast fouling, the void contaminant index (VCI) proposed earlier by Tennakoon et al. [64], which considers the specific gravity of the fouling material, is used:

$V C I=\frac{1+e_{f}}{e_{b}} \times \frac{G_{s b}}{G_{s f}} \times \frac{M_{f}}{M_{b}} \times 100$ where $e_{f}$ : void ratio of coal fines, $e_{b}$ : void ratio of fresh ballast, $G_{s b}$ : specific gravity of ballast, $G_{s f}:$ specific gravity of fouling, $M_{f}$ : weight of fouling, $M_{b}$ : weight of ballast.

DEM modelling of direct shear tests was implemented under normal stresses of $\sigma_{n}=27 \mathrm{kPa}, 51 \mathrm{kPa}$ and $75 \mathrm{kPa}$ [44]. Figure 17 compares the shear stress and shear strain responses for geogrid-stabilised ballast obtained from the DEM with those measured from laboratory tests. It is seen that the simulation data satisfactorily match the laboratory
Fig. 17 Shear stress-strain behaviour and volumetric changes of geogrid-stabilised ballast: a fresh ballast and $\mathbf{b}$ fouled ballast Data source: [44]

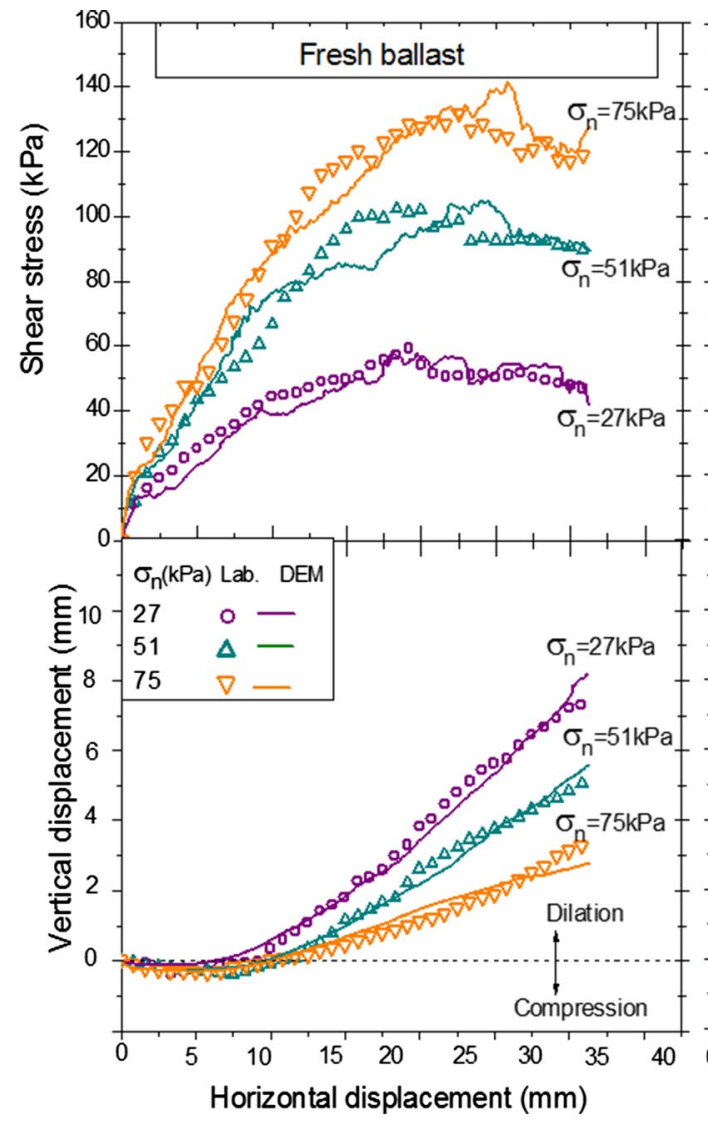

(a)

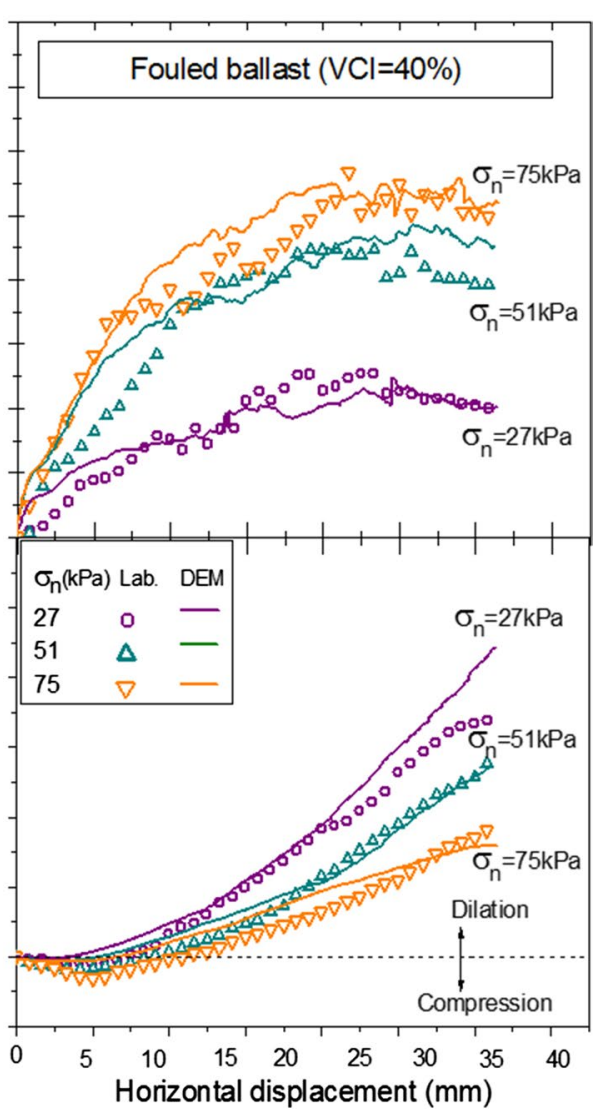

(b) 
data [45]. The ability of the geogrid to enhance the mobilised strength of ballast was confirmed by comparing the results for reinforced and unreinforced ballast assemblies; this is associated with the interlocking that occurred between the aggregates and the geogrids ribs.

\section{Application of geosynthetics in rail infrastructure}

To obtain a better understanding of the load-deformation behaviour of ballasted tracks and the advantages of using geosynthetics, extensive field measurements were undertaken at the Bulli track, in the state of New South Wales, Australia. The experimental track section (total length of $60 \mathrm{~m}$ ) was located between two turnouts and encompassed four sections, each $15 \mathrm{~m}$ long, as shown in Fig. 18a. The ballast and sub-ballast layers were $300 \mathrm{~mm}$ and $150 \mathrm{~mm}$ thick. "Introduction" and "Application of geosynthetics in rail infrastructure" sections included fresh and recycled ballast, respectively, without the inclusion of geosynthetics, whereas "Laboratory study" and "Computational modelling for ballasted rail track" sections were constructed with a geocomposite layer (biaxial geogrid + nonwoven polypropylene geotextile) placed underneath the fresh and recycled ballast, respectively. The particle size distribution of fresh ballast followed the Technical Specification TS 3402 [65]. The recycled ballast was obtained from stockpiles of a recycled plant located near Sydney. The geocomposite layers installed at the ballast-sub-ballast interface consisted of biaxial geogrids placed over nonwoven polypropylene geotextiles (Fig. 18b). Further details of the materials used during construction can be found in previous publications [21-23]. The vertical and lateral stresses developed within the track substructure were recorded by hydraulic earth pressure cells, whereas the vertical and lateral strains of ballast were recorded by settlements pegs and displacement transducers (Fig. 18c, d).

\section{Measured deformation of ballast}

Vertical and horizontal displacements of ballast were monitored against time and then converted to the corresponding number of load cycles based on the annual traffic tonnage,

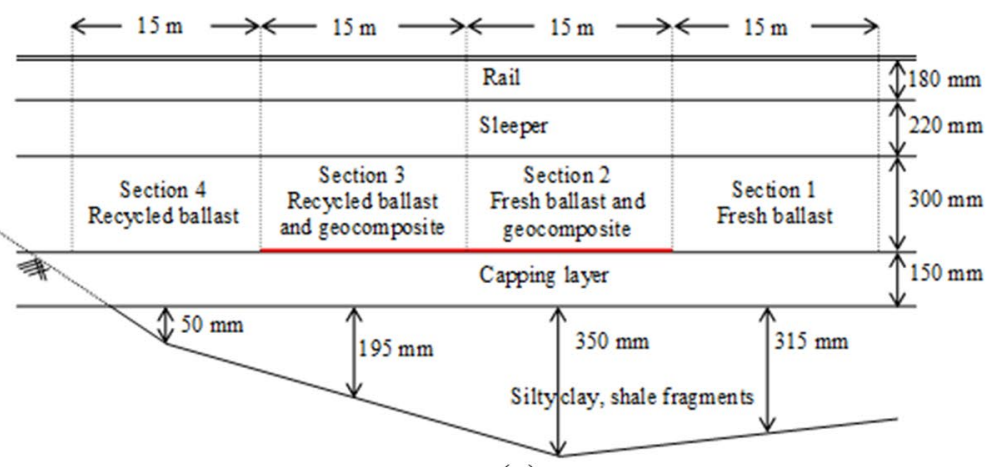

(a)

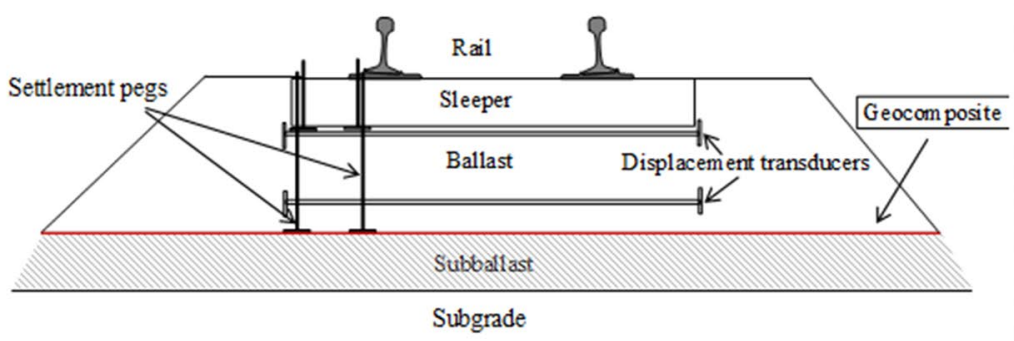

(c)

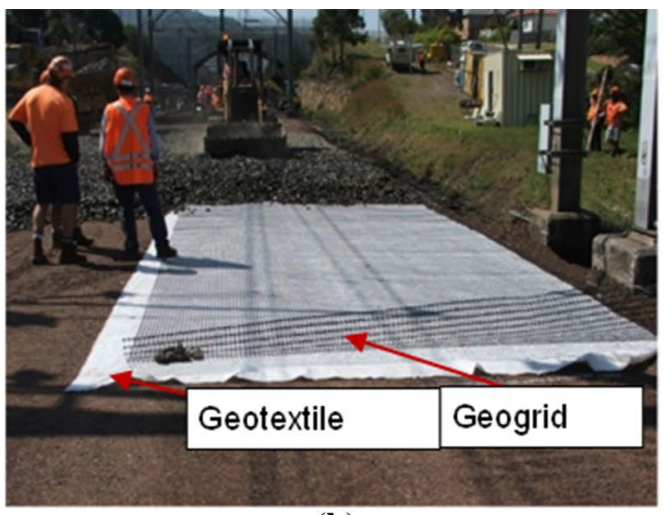

(b)

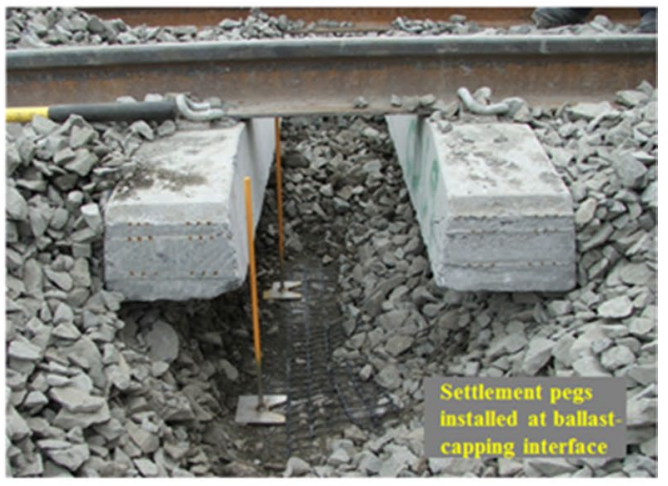

(d)

Fig. 18 a Instrumented track sections, b installation of geosynthetics, $\mathbf{c}$ schematic diagram showing settlement pegs and displacement transducers and $\mathbf{d}$ installation of settlement pegs Data source: [23]; with permission from ASCE) 


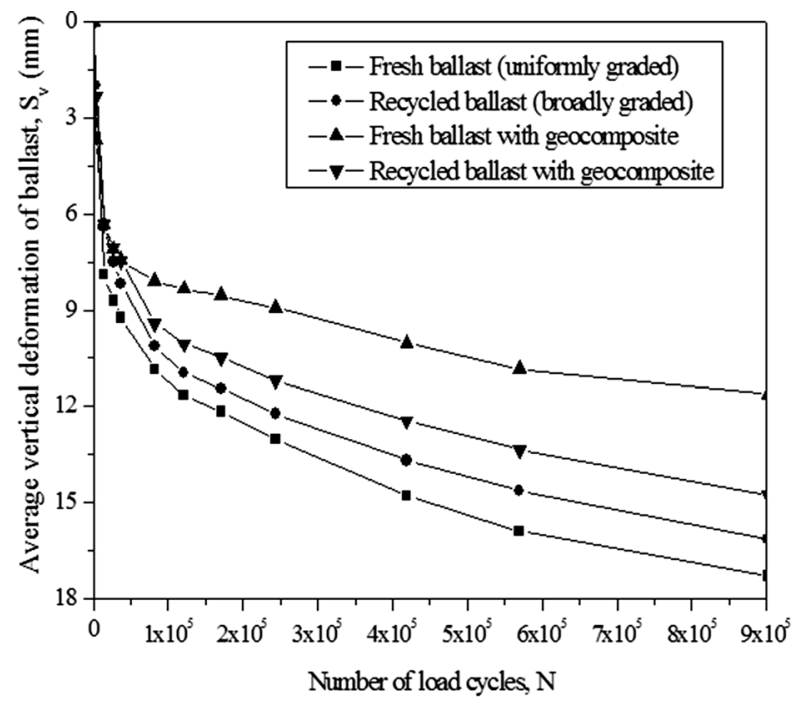

(a)

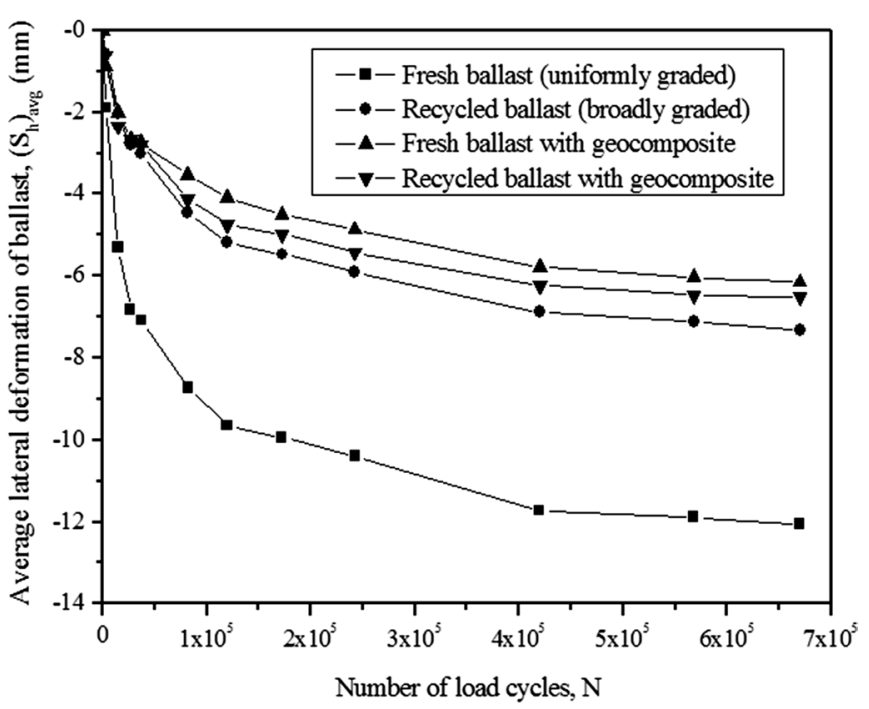

(b)

Fig. 19 Average displacements of ballast: a settlements and b horizontal displacements Data source: [23]; with permission from ASCE

axle load and number of axles per load cycle, as proposed by Selig and Waters [59]. A survey technique was used to measure changes in the level of the tip of the settlement pegs, which was then used to determine track settlement. The average deformations of ballast against the number of cycles $(N)$ are shown in Fig. 19. It can be observed that the rate of increase of vertical $\left(S_{v}\right)$ and lateral strains $\left(S_{l}\right)$ reduced with the number of load cycles. Unlike fresh ballast, the recycled ballast experienced less vertical and lateral deformation, possibly due to the moderate gradation (i.e. $C_{u}=1.8$ ) in comparison with the uniform particle size distribution of fresh ballast $\left(C_{u}=1.5\right)$ used in these field tests. The recycled ballast exhibits reduced breakage because the spent ballast particles are less angular, and thus, the corner breakage associated with high contact forces is less pronounced. The results also show that the geocomposite decreased the vertical strains of fresh and recycled ballast by about 33\% and 9\%, respectively (Fig. 19a). Additionally, it contributed to a reduction of the lateral deformation of fresh and recycled ballast by $49 \%$ and 11\%, respectively, as shown in Fig. $19 \mathrm{~b}$. It should be noted that the lateral displacement is one of the most important parameters affecting track stability, and the geocomposite reinforcement markedly improved the lateral stability because the geogrid apertures provided strong mechanical interlocking with the ballast particles; hence, the internal confining pressure and load bearing capacity of the ballast layer were significantly improved. It was found that recycled ballast when reinforced with a geocomposite layer can perform as well as fresh ballast without reinforcement, with obvious benefits for reduced costs of maintenance.

\section{Measured traffic-induced stresses in ballast}

Figure 20a shows the peak vertical $\left(\sigma_{v}\right)$ and horizontal $\left(\sigma_{l}\right)$ cyclic stresses measured in Sect. 1 (i.e. fresh ballast without geocomposite) during the passage of a coal train having an axle load of 25 tonnes. It is noted that $\sigma_{v}$ decreases by approximately $73 \%$ and $82 \%$ at depths of $300 \mathrm{~mm}$ and $450 \mathrm{~mm}$, respectively. On the other hand, $\sigma_{l}$ only decreases marginally with depth, which implies that artificial inclusions (i.e. geogrids) would be beneficial for additional confinement. It is also observed that although most of the maximum vertical stresses transferred to the ballast layer during the passage of the coal train were lower than $230 \mathrm{kPa}$, one value of $\sigma_{v}$ reached $415 \mathrm{kPa}$ (Fig. 20b); this was attributed to the existence of a wheel flat, thus indicating that much larger dynamic impact forces can be generated by wheel irregularities.

\section{Conclusions}

This paper reviewed some of the salient research outcomes in the area of railroad geomechanics from laboratory testing, field monitoring and computational modelling conducted at the UOW, Australia, over the past two decades. The use of geosynthetics and rubber energy-absorbing materials such as rubber mats and end-of-life tyres to improve the performance of ballasted tracks was elucidated and supported by computational modelling as warranted. The possibility of obtaining an energy-absorbing layer using the blends of steel furnace slag, coal wash and rubber crumb (RC) to replace the traditional sub-ballast (e.g. capping layer) was investigated based 


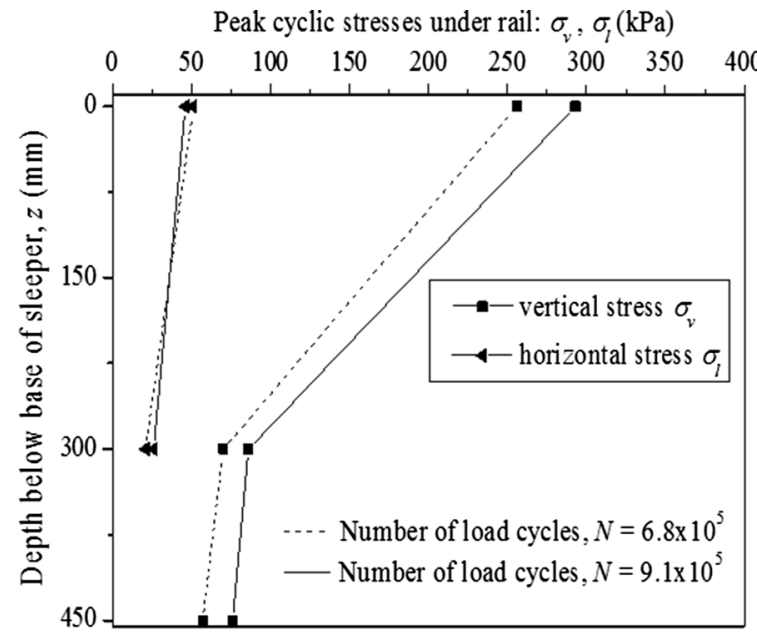

(a)

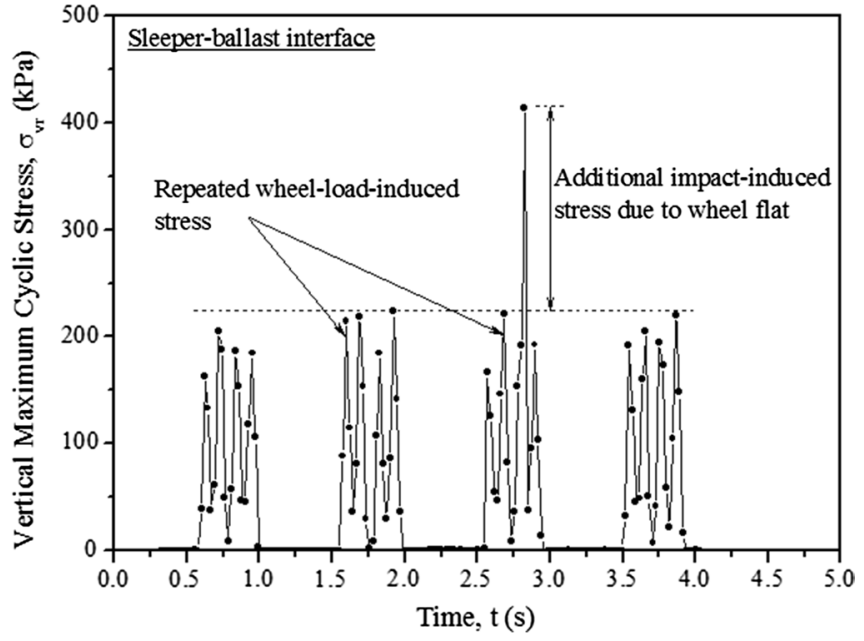

(b)

Fig. 20 Cyclic stress measured under coal trains (100 tonnes wagons): a changes of stresses with depth and b additional impact-induced stress. (Data source: [23])

on geotechnical properties such as the peak friction angle, particle breakage, strain energy density and swell potential. The permanent axial strain and the volumetric strain of the waste mixtures were found to increase with the RC content and confining pressure. The increase in $\mathrm{RC}$ also led to a decrease in the shear modulus and an increase in the damping ratio. From the test results, a blended matrix with SFS/ $\mathrm{CW}=7: 3$ and $10 \% \mathrm{RC}$ was established as an optimum mixture for sub-ballast, with less axial settlement and particle breakage, and higher shear strength and energy-absorbing capacity in comparison with traditional sub-ballast.

An innovative method of reinforcing the upper sub-ballast stratum (capping layer) with recycled rubber tyres for increased stability and longevity of rail tracks was introduced and validated using large-scale cyclic triaxial tests. The results showed that a capping (sub-ballast) layer confined with waste rubber tyres could effectively contribute to reduced ballast degradation and particle movement, while improving the damping properties of the system, and thus its capacity to sustain a higher degree of strain energy.

A series of direct shear tests were also performed on ballast samples with the inclusion of various types of geogrids to evaluate the shear stress-strain and volumetric changes. The results implied that the geogrid could increase the shear strength and friction angles of the ballast assembly. It was confirmed that the aperture ratio $\left(A / D_{50}\right)$ had a significant influence on the interface efficiency factor $(\alpha)$. Based on the obtained results, the optimum geogrid aperture size to maximise the interface shear strength is about $1.20 D_{50}$. Also, the minimum and maximum aperture sizes required to achieve the beneficial effect of geogrids are $0.95 D_{50}$ and $2.50 D_{50}$, respectively.

The effectiveness of geogrids and resilient rubber mats in reducing the ballast permanent deformations and particle degradation under impact loading was evaluated through a series of impact tests using a large-scale impact test device. While the geogrid reinforcement had a relevant role in reducing the ballast permanent strains through ballast-geogrid interlocking and increased lateral confinement, the energyabsorbing rubber mats were effective in attenuating the impact-induced stresses and associated ballast degradation. Therefore, the use of a coupled geogrid-rubber mat system can provide an effective solution to optimise track stability and longevity under severe impact loading.

A series of DEM simulations were implemented for fresh and coal-fouled ballast ( $\mathrm{VCI}=40 \%)$ with and without the inclusion of geogrids. Irregularly shaped aggregates were modelled in DEM by connecting many balls together in approximate sizes and positions. The geogrids were simulated by bonding spheres of $2 \mathrm{~mm}$ diameter at the ribs and $4 \mathrm{~mm}$ diameter at the junctions. The coal fines were represented by generating small spheres into the ballast voids. The predicted shear stress-strain behaviour from the DEM model for fresh and fouled ballast matched reasonably well that measured experimentally, proving that the detailed DEM model was able to simulate the stress-strain responses of ballast. Coal fines were found to reduce the interlock between the ballast grains and geogrids, which resulted in lower shear strength. The findings provided a better understanding of the ballast-geogrid interaction mechanisms, long-term deformation and degradation of ballast, as well as 
the beneficial effects of using geosynthetics for the improved performance of ballasted tracks.

The results of an extensive field monitoring program to investigate the ability of geosynthetics to enhance track stability were presented and discussed. Both fresh and recycled ballast were used for the purpose of comparison, and a geocomposite consisting of a biaxial geogrid placed over a nonwoven geotextile was installed underneath the ballast layer. The field measurements showed that the geocomposite reinforcement contributed to a significant decrease in track settlement and lateral spreading. It was further observed that recycled ballast when reinforced with a geocomposite layer could achieve similar performance to that of fresh ballast without reinforcement, and therefore, the use of reinforced recycled ballast could be considered as an attractive solution from economic and environmental points of view. There is no doubt that improved geogrid-ballast interaction, increased confinement of the capping layer by the use of rubber tyres and the use of shock absorbing rubber mats particularly on harder sub-grades lead to more resilient tracks with increased stability and longevity, a result that bears significant implications on track maintenance costs.

Acknowledgements The authors wish to acknowledge the Australian Research Council (ARC) and Industry partners for providing support through the ARC Industrial Transformation Training Centre for Advanced Technologies in Rail Track Infrastructure (ITTC-Rail). The efforts of past doctoral students, Dr. Syed K. Hussaini, Dr. Nayoma Tennakoon, Dr. Mehdi Biabani and Dr. Joanne Lackenby among others, and postdoctoral research fellows, Dr. Sanjay Nimbalkar and Dr. Qideng Sun that have contributed to the contents of this keynote paper are also gratefully appreciated, as well as the support of colleagues A/ Prof. Jayan Vinod, A/Prof. Cholachat Rujikiatkamjorn and Dr. Ana Heitor over the past years. The authors sincerely acknowledge Rail Manufacturing Cooperative Research Centre (funded jointly by participating rail organisations and the Australian Federal Government's Business Cooperative Research Centres Program) through two Projects, R2.5.1 and R2.5.2. The authors also thank the Australasian Centre for Rail Innovation (ACRI), Tyre Stewardship Australia (TSA), Global Synthetics Pty Ltd, Naue GmbH \& Co. KG, Foundation Specialists Group, Sydney Trains (formerly RailCorp), Australian Rail Track Corporation (ARTC), Bridgestone Corporation, among others. The cooperation of David Christie (formerly Senior Geotechnical Consultant, RailCorp), Tim Neville (ARTC) and Michael Martin (Aurizon/QLD Rail) during these industry linkages is gratefully appreciated. Salient contents from these previous studies are reproduced herein with kind permission from the original sources, including ASCE-JGGE, Canadian Geotechnical Journal, Computers and Geotechnics, Geotextiles and Geomembranes, among others. The authors are also grateful to UOW technical staff, namely Alan Grant, Cameron Neilson, Duncan Best and Ritchie McLean, for their assistance during laboratory and field studies.

\section{References}

1. AS 2758.7 (1996) Aggregates and rock for engineering purposes. Part 7: Railway Ballast. Standard Australia, Sydney, Australia
2. ASTM D6270 (2008) Standard practice for use of scrap tyres in civil engineering applications. ASTM D International, West Conshohocken

3. Aursudkij B, McDowell GR, Collop AC (2009) Cyclic loading of railway ballast under triaxial conditions and in a railway test facility. Granul Matter 11:391-401

4. Bathurst RJ, Raymond GP (1987) Geogrid reinforcement of ballasted track. Transp Res Rec 1153:8-14

5. Biabani MM, Ngo NT, Indraratna B (2016) Performance evaluation of railway subballast stabilised with geocell based on pull-out testing. Geotext Geomembr 44(4):579-591

6. Brown SF, Kwan J, Thom NH (2007) Identifying the key parameters that influence geogrid reinforcement of railway ballast. Geotext Geomembr 25(6):326-335

7. Cundall PA, Strack ODL (1979) A discrete numerical model for granular assemblies. Geotechnique 29(1):47-65

8. Fernandes G, Palmeira EM, Gomes RC (2008) Performance of geosynthetic-reinforced alternative sub-ballast material in a railway track. Geosynth Int 15(5):311-321

9. Ferreira FB, Indraratna B (2017) Deformation and degradation response of railway ballast under impact loading-effect of artificial inclusions. In: First international conference on rail transportation, Chengdu, China, July 2017, Paper ID: 362

10. Ferreira TM, Teixeira PF, Cardoso R (2012) Impact of bituminous subballast on railroad track deformation considering atmospheric actions. J Geotech Geoenviron Eng 137(3):288-292

11. Frederick CO, Round DJ (1985) Vertical track loading. Track Technology. Thomas Telford, London, pp 135-149

12. Hussaini SKK, Indraratna B, Vinod JS (2016) A laboratory investigation to assess the functioning of railway ballast with and without geogrids. Transp Geotech 6:45-54

13. Indraratna B (2016) Railroad performance with special reference to ballast and substructure characteristics. 1st Proctor Lecture of ISSMGE. Transp Geotech 7:74-114

14. Indraratna B, Hussaini SKK, Vinod JS (2012) On the shear behaviour of ballast-geosynthetic interfaces. Geotech Test J 35(2):1-8

15. Indraratna B, Lackenby J, Christie D (2005) Effect of confining pressure on the degradation of ballast under cyclic loading. Geotechnique 55(4):325-328

16. Indraratna $B$, Navaratnarajah $S K$, Nimbalkar $S$, Rujikiatkamjorn $C$ (2014) Use of shock mats for enhanced stability of railroad track foundations. Aust Geomech J 49(4):101-110

17. Indraratna B, Ngo N, Nimbalkar S, Rujikiatkamjorn C (2018a) Two decades of advancement in process simulation testing of ballast strength, deformation, and degradation. Railroad Ballast Testing and Properties, ASTM STP1605. Stark RSTD, Swan Jr RF (Eds). ASTM International, West Conshohocken, pp 1-28. http:// dx.doi.org/10.1520/STP160520170029

18. Indraratna B, Ngo NT, Rujikiatkamjorn C (2011) Behavior of geogrid-reinforced ballast under various levels of fouling. Geotext Geomembr 29(3):313-322

19. Indraratna B, Ngo NT, Rujikiatkamjorn C (2013) Deformation of coal fouled ballast stabilized with geogrid under cyclic load. J Geotech Geoenviron Eng 139(8):1275-1289

20. Indraratna B, Ngo NT, Rujikiatkamjorn C, Vinod J (2014) Behaviour of fresh and fouled railway ballast subjected to direct shear testing - a discrete element simulation. Int J Geomech ASCE 14(1):34-44

21. Indraratna B, Ngo T (2018) Ballast railroad design: smart-uow approach. CRC Press, London

22. Indraratna $B$, Nimbalkar $S$, Anantanasakul $P$, Rujikiatkamjorn $C$, Neville T (2013b) Performance monitoring of rail tracks stabilized by geosynthetics and shock mats: case studies at Bulli and Singleton in Australia. Geotechnical Special Publication, pp 19-33

23. Indraratna $B$, Nimbalkar $S$, Christie $D$, Rujikiatkamjorn $C$, Vinod J (2010) Field assessment of the performance of a ballasted rail 
track with and without geosynthetics. J Geotech Geoenviron Eng 136(7):907-917

24. Indraratna B, Nimbalkar SS, Ngo NT, Neville T (2016) Performance improvement of rail track substructure using artificial inclusions-experimental and numerical studies. Transp Geotech 8:69-85

25. Indraratna B, Nimbalkar S, Rujikiatkamjorn C (2014) Enhancement of rail track performance through utilisation of geosynthetic inclusions. Geotech Eng J 45(1):17-27

26. Indraratna B, Qi YJ, Heitor A (2018) Evaluating the properties of mixtures of steel furnace slag, coal wash, and rubber crumbs used as subballast. J Mater Civil Eng 30(1):04017251

27. Indraratna B, Salim W, Rujikiatkamjorn C (2011) Advanced rail geotechnology—ballasted track. CRC Press, London

28. Indraratna B, Sun Q, Heitor A, Grant J (2018) Performance of rubber tire-confined capping layer under cyclic loading for railroad conditions. J Mater Civ Eng 30(3):06017021

29. Indraratna B, Sun Q, Ngo NT, Rujikiatkamjorn C (2017) Current research into ballasted rail tracks: model tests and their practical implications. Aust J Struct Eng 18(3):204-220

30. Itasca (2016) Particle flow code in three dimensions (PFC3D). Itasca Consulting Group Inc, Minnesota

31. Jeffs T, Tew GP (1991) A review of track design procedures: sleepers and ballast. Railways of Australia, Melbourne

32. Jenkins HM, Stephenson JE, Clayton GA, Moorland JW, Lyon D (1974) The effect of track and vehicle parameters on wheel/ rail vertical dynamic forces. Railw Eng J 3(1):2-16

33. Kaewunruen S, Remennikov AM (2010) Dynamic crack propagations in prestressed concrete sleepers in railway track systems subjected to severe impact loads. ASCE J Struct Eng 136(6):749-754

34. Li B, Huang MS, Zeng XW (2016) Dynamic behavior and liquefaction analysis of recycled-rubber sand mixtures. J Mater Civ Eng 28(11):04016122

35. Li D, Hyslip JP, Sussmann TR, Chrismer SM (2016) Railway geotechnics. CRC Press, Boca Raton

36. Lobo-Guerrero S, Vallejo LE (2006) Discrete element method analysis of rail track ballast degradation during cyclic loading. Granul Matter 8(3-4):195-204

37. Marsal RJ (1967) Large scale testing of rockfill materials. J Soil Mech Found Div ASCE 93(2):27-43

38. McDowell GR, Bolton MD (1998) On the micromechanics of crushable aggregates. Geotechnique 48(5):667-679

39. McDowell GR, Harireche O, Konietzky H, Brown SF, Thom NH (2006) Discrete element modelling of geogrid-reinforced aggregates. Proc ICE Geotech Eng 159(1):35-48

40. McDowell GR, Lim WL, Collop AC, Armitage R, Thom NH (2008) Comparison of ballast index tests for railway trackbeds. Geotech Eng 157(3):151-161

41. Navaratnarajah SK, Indraratna B (2017) Use of rubber mats to improve the deformation and degradation behavior of rail ballast under cyclic loading. J Geotech Geoenviron Eng 143:04017015. https://doi.org/10.1061/(asce)gt.1943-5606.0001669

42. Navaratnarajah SK, Indraratna B, Ngo NT (2018) Influence of under sleeper pads on ballast behavior under cyclic loadingexperimental and numerical Studies. J Geotech Geoenviron Eng 144:04018068

43. Ngo NT, Indraratna B, Ferreira FB, Rujikiatkamjorn C (2018) Improved performance of geosynthetics enhanced ballast: laboratory and numerical studies. In: Proceedings of the Institution of Civil Engineers-Ground Improvement, pp 1-21

44. Ngo NT, Indraratna B, Rujikiatkamjorn C (2014) DEM simulation of the behaviour of geogrid stabilised ballast fouled with coal. Comput Geotech 55:224-231
45. Ngo NT, Indraratna B, Rujikiatkamjorn C (2016) Modelling geogrid-reinforced railway ballast using the discrete element method. Transp Geotech 8:86-102

46. Ngo NT, Indraratna B, Rujikiatkamjorn C (2017) Micromechanics-based investigation of fouled ballast using large-scale triaxial tests and discrete element modeling. J Geotech Geoenviron Eng 134(2):04016089

47. Ngo NT, Indraratna B, Rujikiatkamjorn C (2017) Stabilisation of track substructure with geo-inclusions-experimental evidence and DEM simulation. Int J Rail Transp 5(2):63-86

48. Ngo NT, Indraratna B, Rujikiatkamjorn C (2017) A study of the geogrid-subballast interface via experimental evaluation and discrete element modelling. Granul Matter 19(3):54

49. Ngo NT, Indraratna B, Rujikiatkamjorn C, Biabani MM (2016) Experimental and discrete element modeling of geocell-stabilised subballast subjected to cyclic loading. J Geotech Geoenviron Eng 142(4):04015100

50. Nguyen TT, Indraratna B (2016) Hydraulic behaviour of parallel fibres under longitudinal flow: a numerical treatment. Can Geotech J 53(7):1081-1092

51. Nimbalkar S, Indraratna B (2016) Improved performance of ballasted rail track using geosynthetics and rubber shockmat. J Geotech Geoenviron Eng 142(8):04016031

52. Nimbalkar S, Indraratna B, Dash S, Christie D (2012) Improved performance of railway ballast under impact loads using shock mats. J Geotech Geoenviron Eng 138(3):281-294

53. O'Sullivan C, Cui L, O'Neill C (2008) Discrete element analysis of the response of granular materials during cyclic loading. Soils Found 48(4):511-530

54. Powrie W, Yang LA, Clayton CRI (2007) Stress changes in the ground below ballasted railway track during train passage. Proc Inst Mech Eng F J Rail Rapid Transit 221:247-261

55. Qi YJ, Indraratna B, Heitor A, Vinod JS (2018) Effect of rubber crumbs on the cyclic behaviour of steel furnace slag and coal wash mixtures. J Geotech Geoenviron Eng 144(2):04017107

56. Qi Y, Indraratna B, Heitor A, Vinod JS (2018b) The influence of rubber crumbs on the energy absorbing property of waste mixtures. In: Proceedings of the international symposium on geotechnics of transportation infrastructure (ISGTI 2018). New Delhi, India, pp 455-460

57. Rochard BP, Schmidt F (2004) Benefits of lower-mass trains for high speed rail operations. Proc Inst Civil Eng Transp 157(1):51-64

58. Rujikiatkamjorn C, Indraratna B, Ngo NT, Coop M (2012) A laboratory study of railway ballast behaviour under various fouling degree. In: The 5th Asian regional conference on geosynthetics, pp 507-514

59. Selig ET, Waters JM (1994) Track geotechnology and substructure management. Thomas Telford, London

60. Sol-Sanchez M, Thom NH, Moreno-Navarro F, Rubio-Gamez MC, Airey GD (2015) A study into the use of crumb rubber in railway ballast. Constr Build Mater 75:19-24

61. Suiker ASJ, Selig ET, Frenkel R (2005) Static and cyclic triaxial testing of ballast and subballast. J Geotech Geoenviron Eng ASCE 131(6):771-782

62. Sun QD, Indraratna B, Nimbalkar S (2015) Deformation and degradation mechanisms of railway ballast under high frequency cyclic loading. J Geotech Geoenviron Eng 142(1):04015056

63. Sussmann TR, Ruel M, Chrismer SM (2012) Source of ballast fouling and influence considerations for condition assessment criteria. Transportation Research Record: Journal of the Transportation Research Board, Transportation Research Board of the National Academies, No. 2289. Washington, D.C., 2012, pp 87-94

64. Tennakoon N, Indraratna B, Rujikiatkamjorn C, Nimbalkar S, Neville T (2012) The role of ballast-fouling characteristics 
on the drainage capacity of rail substructure. Geotech Test J 35(4): $1-11$

65. T.S. 3402 (2001) Specification for supply of aggregates for Ballast. Rail Infrastructure Corporation of NSW, Sydney

66. Tutumluer E, Dombrow W, Huang H (2008) Laboratory characterization of coal dust fouled ballast behaviour. In: AREMA 2008 annual conference \& exposition, Salt Lake City, UT, USA
67. Tutumluer E, Huang H, Bian X (2012) Geogrid-aggregate interlock mechanism investigated through aggregate imagingbased discrete element modeling approach. Int J Geomech 12(4):391-398

68. Zheng YF, Kevin SG (2000) Dynamic properties of granulated rubber/sand mixtures. Geotech Test J 23(3):338-344 